\title{
River water quality model no. 1 (RWQM1): Il. Biochemical process equations
}

Reichert, P.; Borchardt, D.; Henze, Mogens; Rauch, W.; Shanahan, P.; Somlyody, L.; Vanrolleghem, P.

Published in:

Water Science and Technology

Publication date:

2001

Document Version

Publisher's PDF, also known as Version of record

Link back to DTU Orbit

Citation (APA):

Reichert, P., Borchardt, D., Henze, M., Rauch, W., Shanahan, P., Somlyody, L., \& Vanrolleghem, P. (2001). River water quality model no. 1 (RWQM1): II. Biochemical process equations. Water Science and Technology, 43(5), 11-30.

\section{General rights}

Copyright and moral rights for the publications made accessible in the public portal are retained by the authors and/or other copyright owners and it is a condition of accessing publications that users recognise and abide by the legal requirements associated with these rights.

- Users may download and print one copy of any publication from the public portal for the purpose of private study or research.

- You may not further distribute the material or use it for any profit-making activity or commercial gain

- You may freely distribute the URL identifying the publication in the public portal 


\title{
River Water Quality Model no. 1 (RWQM 1): II. Biochemical process equations
}

\author{
P. Reichert*, D. Borchardt**, M. Henze***, W. Rauch*, P. Shanahan****, L. Somlyódy ${ }^{\dagger}$ and \\ P. Vanrolleghem ${ }^{\ddagger}$ \\ *EAW AG , C H-8600 Dübendorf, S witzerland \\ **U niversity of Kassel, Kurt W olters-S tr. 3, D-34215 Kassel, G ermany \\ ***Dept. of Environ. Sci. and Eng., Tech. Univ. of Denmark, B Id. 115, 2800 Lyngby, Denmark \\ ****H ydroA nalysis Inc., $481 \mathrm{G}$ reat Road, Acton M A 01720, US A \\ ${ }^{\dagger} B$ udapest University of Technology, M ügyetem rkp. 3, 1111 Budapest, Hungary

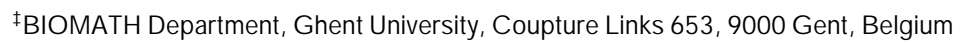

\begin{abstract}
In this paper, biochemical process equations are presented as a basis for water quality modelling in rivers under aerobic and anoxic conditions. These equations are not new, but they summarise parts of the development over the past 75 years. The primary goals of the presentation are to stimulate communication among modellers and field-oriented researchers of river water quality and of wastewater treatment, to facilitate practical application of river water quality modelling, and to encourage the use of elemental mass balances for the derivation of stoichiometric coefficients of biochemical transformation processes. This paper is part of a series of three papers. In the first paper, the general modelling approach is described; in the present paper, the biochemical process equations of a complex model are presented; and in the third paper, recommendations are given for the selection of a reasonable submodel for a specific application. Keywords Activated sludge models; eutrophication; nitrification; denitrification; dissolved oxygen; elemental mass balance; river; water quality models
\end{abstract}

\section{Introduction}

The IWA (formerly IAWQ) Task Group on River Water Quality Modelling was formed to create a scientific and technical base from which to formulate consistent river water quality models and guidelines for their use. This effort is intended to lead to the development of river water quality models that are compatible with the existing IAWQ (formerly IAWPRC) activated sludge models (ASM1, ASM2, and ASM3; Henze et al. 2000) and can be straightforwardly linked to them. Specifically, water quality constituents and model state variables characterising $\mathrm{C}, \mathrm{O}, \mathrm{N}$, and $\mathrm{P}$ cycling are to be selected for the basic model.

In a first effort, the task group analysed the state of the art of river water quality modelling, its problems, and possible future directions (Rauch et al., 1998; Shanahan et al., 1998; Somlyódy et al., 1998). This paper is the second of a three-part series that gives recommendations for model formulation. The first paper (Shanahan et al., 2001) contains a description of the modelling approach. The present paper contains equations for the formulation of biochemical conversion processes for a basic river water quality model which tries to include the most important processes for $\mathrm{C}, \mathrm{O}, \mathrm{N}$, and $\mathrm{P}$ cycling in a river under aerobic or anoxic conditions. This model is relatively complicated and its parameters may rarely be identifiable in practice. However, the model serves as a scientifically consistent framework as a basis for simplifications depending on specific conditions. In the third paper (Vanrolleghem et al., 2001), recommendations are given for selecting the appropriate biochemical submodel for a specific application. In addition to these three theoretical papers, two model applications to actual data sets demonstrate the usefulness of the proposed approach (Reichert, 2001; Borchardt and Reichert, 2001). 
Since 1925 (Streeter and Phelps, 1925) many river water quality modelling efforts have been performed, however, many of them are not consistent (e.g. mass balance of the watersediment system is not fulfilled). In addition, none of them is compatible with the well based activated sludge models and thus they are not suited for an integrated wastewater treatment plant - river water quality analysis. The goal of this and the companion papers is to transfer coherent process formulations from activated sludge modelling to the riverine environment and to give recommendations of which process formulations are advantageous to be used under which circumstances. Major motivation was given by the well known water quality model and computer program QUAL2E (Brown and Barnwell, 1987) and the activated sludge models cited above.

For the following reasons, we decided to base our approach on the elemental composition of organisms and the stoichiometry of biochemical conversion processes instead of only using chemical oxygen demand (COD) as it is common practice in wastewater treatment.

- There is increasing realisation of the importance of elemental composition and of the stoichiometry of biochemical conversion processes in ecology (Elser and Urabe, 1999).

- Elemental analyses of organisms are increasingly applied in the environmental sciences (Elser et al., 1995; Norland, et al., 1995; Fagerbakke et al., 1996).

- Other measurement units of biomass than COD, such as cell counts, organic carbon content, dry weight, or elemental mass fractions, are widely used to quantify measurements in natural systems. It seems not to be reasonable to propose to replace such measurements by COD measurements only.

- The use of elemental mass fractions builds a rigorous theoretical base to biochemical conversion processes that allows to derive most of the other commonly used quantification measures. Although the actual elemental mass fractions will not be known in any application, their use at least makes the underlying assumptions of the model explicit. Sensitivity analysis can then be used to distinguish between more and less important assumptions.

\section{Simplying assumptions}

The equations of the basic model are based on the following simplifying assumptions.

1. The elemental composition of all compounds and organisms as well as the stoichiometry of all processes is assumed to be constant in time for each model application (but they may be different for different model applications). In the current version of the model, the elemental composition considers only carbon $(\mathrm{C})$, hydrogen $(\mathrm{H})$, oxygen $(\mathrm{O})$, nitrogen $(\mathrm{N})$ and phosphorus $(\mathrm{P})$. Conversion formulas and stoichiometric coefficients are inaccurate if other elements significantly contribute to dry mass or COD. As a special case of this simplification, growth limitation of diatoms by silicate is not considered.

2. No adaptation takes place and changes in the composition within organism classes are neglected. This means that the time dependence of kinetic expressions and parameters is only via the dependence on other model constituents or environmental conditions, such as temperature, light, or $\mathrm{pH}$.

3. It is assumed that nitrate is always available. If anaerobic processes in the water column or the river sediment are of significance for the turnover of the compounds considered in the model, the model must be extended to account for these effects (e.g. sulphur is not considered in the model).

\section{Composition of organic compounds and organisms}

The limitations to constant elemental composition of compounds and organisms and to a given set of elements to be considered make it possible to use the mass fractions of these 
elements as model parameters. The formulation of stoichiometric coefficients of conversion processes as functions of these parameters simplifies the adaptation of the model to cases where different composition of organic material seems appropriate. Because different units are used to characterise organic material, conversion formulas are given between mass of organic substances (OM; this is dry mass for particulate substances), organic carbon (orgC) and chemical oxygen demand (COD). The last measurement unit is natural in the case of oxygen depletion simulations and it is of special importance for linkage to sewage treatment simulations (where organic substances are usually characterised by COD and ratios of $\mathrm{N}$ and $\mathrm{P}$ to $\mathrm{COD})$. The composition of organic matter is approximated by mass fractions of the elements $\mathrm{C}, \mathrm{H}, \mathrm{O}, \mathrm{N}$, and $\mathrm{P}$. The mass fractions of all other elements are neglected. For this reason, the composition of organic material can uniquely be described by the mass fractions

$\alpha_{\mathrm{C}}, \alpha_{\mathrm{H}}, \alpha_{\mathrm{O}}, \alpha_{\mathrm{N}}, \alpha_{\mathrm{P}}$

of $\mathrm{C}, \mathrm{H}, \mathrm{O}, \mathrm{N}$, and $\mathrm{P}$, where a mass fraction represents the fraction of the total mass of organic substance contributed by a particular chemical element. Because other elements are neglected, these mass fractions fulfil the constraint (cf. simplifying assumption 1 above)

$\alpha_{\mathrm{C}}+\alpha_{\mathrm{H}}+\alpha_{\mathrm{O}}+\alpha_{\mathrm{N}}+\alpha_{\mathrm{P}}=1$

The mass fractions (1) make a formulation of organic matter by a chemical formula possible.

For $1 \mathrm{~g}$ of organic matter this formula is given as (indices are interpreted as fractions of moles)

$\mathrm{C}_{\alpha_{\mathrm{C}} / 12} \mathrm{H}_{\alpha_{\mathrm{H}}} \mathrm{O}_{\alpha_{\mathrm{O}} / 16} \mathrm{~N}_{\alpha_{\mathrm{N}} / 14} \mathrm{P}_{\alpha_{\mathrm{P}} / 31}$.

The chemical formula for the mineralisation process can then be determined using conservation principles for the elements $\mathrm{C}, \mathrm{H}, \mathrm{O}, \mathrm{N}, \mathrm{P}$, and for charge. This results in

$$
\begin{aligned}
& \mathrm{C}_{\alpha_{\mathrm{C}} / 12} \mathrm{H}_{\alpha_{\mathrm{H}}} \mathrm{O}_{\alpha_{\mathrm{O}} / 16} \mathrm{~N}_{\alpha_{\mathrm{N}} / 14} \mathrm{P}_{\alpha_{\mathrm{P}} / 31}+\left(\frac{\alpha_{\mathrm{C}}}{12}+\frac{\alpha_{\mathrm{H}}}{4}-\frac{\alpha_{\mathrm{O}}}{32}-\frac{3 \alpha_{\mathrm{N}}}{56}+\frac{5 \alpha_{\mathrm{P}}}{124}\right) \mathrm{O}_{2}+\left(\frac{\alpha_{\mathrm{N}}}{14}-\frac{2 \alpha_{\mathrm{P}}}{31}\right) \mathrm{H}^{+} \\
& \rightarrow\left(\frac{\alpha_{\mathrm{H}}}{2}-\frac{3 \alpha_{\mathrm{N}}}{28}-\frac{3 \alpha_{\mathrm{P}}}{62}\right) \mathrm{H}_{2} \mathrm{O}+\frac{\alpha_{\mathrm{C}}}{12} \mathrm{CO}_{2}+\frac{\alpha_{\mathrm{N}}}{14} \mathrm{NH}_{4}^{+}+\frac{\alpha_{\mathrm{P}}}{31} \mathrm{HPO}_{4}^{2-} .
\end{aligned}
$$

This formula leads to the conversion of mass of organic matter to COD as follows:

$$
\mathrm{COD}=32\left(\frac{\alpha_{\mathrm{C}}}{12}+\frac{\alpha_{\mathrm{H}}}{4}-\frac{\alpha_{\mathrm{O}}}{32}-\frac{3 \alpha_{\mathrm{N}}}{56}+\frac{5 \alpha_{\mathrm{P}}}{124}\right) \mathrm{OM}
$$

The conversion of mass of organic matter to organic carbon is evidently given by

$$
\operatorname{orgC}=\alpha_{\mathrm{C}} \mathrm{OM} \text {. }
$$

The mass fractions of $\mathrm{N}$ and $\mathrm{P}$ per unit of COD, which are usually used as parameters in activated sludge models, are then given as

$$
i_{\mathrm{N}}=\frac{\alpha_{\mathrm{N}}}{32\left(\frac{\alpha_{\mathrm{C}}}{12}+\frac{\alpha_{\mathrm{H}}}{4}-\frac{\alpha_{\mathrm{O}}}{32}-\frac{3 \alpha_{\mathrm{N}}}{56}+\frac{5 \alpha_{\mathrm{P}}}{124}\right)}, \quad i_{\mathrm{P}}=\frac{\alpha_{\mathrm{P}}}{32\left(\frac{\alpha_{\mathrm{C}}}{12}+\frac{\alpha_{\mathrm{H}}}{4}-\frac{\alpha_{\mathrm{O}}}{32}-\frac{3 \alpha_{\mathrm{N}}}{56}+\frac{5 \alpha_{\mathrm{P}}}{124}\right)} .
$$

Note that the parameters $i_{\mathrm{N}}$ and $i_{\mathrm{P}}$ are not sufficient for a complete characterisation of the composition of organic substances. For a complete characterisation that considers the elements $\mathrm{C}, \mathrm{H}, \mathrm{O}, \mathrm{N}, \mathrm{P}$, two additional parameters describing the ratios of $\mathrm{C}$ to $\mathrm{H}$ and of $\mathrm{C}$ to $\mathrm{O}$ (or $\mathrm{C}$ to $\mathrm{COD}$ and $\mathrm{H}$ to $\mathrm{COD}$ ) would be required.

\section{Components used in the model}

The following components are distinguished in the model:

- $S_{\mathrm{S}}$ : dissolved organic substances, assumed to be available for rapid biodegradation by 
heterotrophic organisms: $\mathrm{C}_{\alpha_{\mathrm{C}, \mathrm{SS}} / 12} \mathrm{H}_{\alpha_{\mathrm{H}, \mathrm{SS}}} \mathrm{O}_{\alpha_{\mathrm{O}, \mathrm{SS}} / 16} \mathrm{~N}_{\alpha_{\mathrm{N}, \mathrm{SS}} / 14} \mathrm{P}_{\alpha_{\mathrm{P}, \mathrm{SS}} / 31}$.

- $S_{\mathrm{I}}$ : inert dissolved organic substances: $\mathrm{C}_{\alpha_{\mathrm{C}, \mathrm{SI}} / 12} \mathrm{H}_{\alpha_{\mathrm{H}, \mathrm{SI}}} \mathrm{O}_{\alpha_{\mathrm{O}, \mathrm{SI}} / 16} \mathrm{~N}_{\alpha_{\mathrm{N}, \mathrm{SI}} / 14} \mathrm{P}_{\alpha_{\mathrm{P}, \mathrm{SI}} / 31}$. These substances are assumed not to be biodegradable within the time frame of relevance.

- $S_{\mathrm{NH} 4}$ : Ammonium nitrogen: $\mathrm{NH}_{4}^{+}-\mathrm{N}$.

- $S_{\mathrm{NH} 3}$ : Ammonia nitrogen: $\mathrm{NH}_{3}-\mathrm{N}$.

- $S_{\mathrm{NO} 2}$ : Nitrite-nitrogen: $\mathrm{NO}_{2}^{-}-\mathrm{N}$.

- $S_{\mathrm{NO} 3}$ : Nitrate-nitrogen: $\mathrm{NO}_{3}^{-}-\mathrm{N}$.

- $S_{\mathrm{HPO} 4}$ : Part of inorganic dissolved phosphorus (inorganic dissolved phosphorus is $\mathrm{S}_{\mathrm{HPO} 4}+\mathrm{S}_{\mathrm{H} 2 \mathrm{PO} 4}$, the distribution depends on $\mathrm{pH}$ ). For stoichiometric calculations assumed to be $\mathrm{HPO}_{4}^{2-}-\mathrm{P}$.

- $S_{\mathrm{H} 2 \mathrm{PO} 4}$ : Part of inorganic dissolved phosphorus (inorganic dissolved phosphorus is $S_{\mathrm{HPO} 4}+S_{\mathrm{H} 2 \mathrm{PO} 4}$, the distribution depends on $\mathrm{pH}$ ). For stoichiometric calculations assumed to be $\mathrm{H}_{2} \mathrm{PO}_{4}^{-}-\mathrm{P}$.

- $S_{\mathrm{O} 2}$ : Dissolved oxygen: $\mathrm{O}_{2}$.

- $S_{\mathrm{CO} 2}$ : Sum of dissolved carbon dioxide and $\mathrm{H}_{2} \mathrm{CO}_{3}$ measured as carbon mass: $\mathrm{CO}_{2}-\mathrm{C}+$ $\mathrm{H}_{2} \mathrm{CO}_{3}-\mathrm{C}$.

- $S_{\mathrm{HCO} 3}$ : Bicarbonate measured as carbon mass: $\mathrm{HCO}_{3}^{-}-\mathrm{C}$.

- $S_{\mathrm{CO} 3}$ : Dissolved $\mathrm{CO}_{3}^{2-}$ measured as carbon mass: $\mathrm{CO}_{3}^{2-}-\mathrm{C}$.

- $S_{\mathrm{H}}$ : Hydrogen ions: $\mathrm{H}^{+}$. $\mathrm{pH}$ can then be calculated as $-\log 10\left(S_{\mathrm{H}} / 1 \mathrm{gH} / \mathrm{l}\right)$.

- $S_{\mathrm{OH}}: \mathrm{OH}^{-}$ions measured as hydrogen mass (or moles): $\mathrm{OH}^{-}-\mathrm{H}$.

- $S_{\mathrm{Ca}}$ : Dissolved $\mathrm{Ca}^{2+}$ ions: $\mathrm{Ca}^{2+}$.

- $X_{\mathrm{H}}$ : Heterotrophic organisms that are assumed to be able to grow aerobically as well as anoxically (at a slightly slower rate): $\mathrm{C}_{\alpha_{\mathrm{C}, \mathrm{XH}} / 12} \mathrm{H}_{\alpha_{\mathrm{H}, \mathrm{XH}}} \mathrm{O}_{\alpha_{\mathrm{O}, \mathrm{XH}} / 16} \mathrm{~N}_{\alpha_{\mathrm{N}, \mathrm{XH}} / 14} \mathrm{P}_{\alpha_{\mathrm{P}, \mathrm{XH}} / 31}$.

- $X_{\mathrm{N} 1}$ : Organisms oxidising ammonia to nitrite: $\mathrm{C}_{\alpha_{\mathrm{C}, \mathrm{N} 1} / 12} \mathrm{H}_{\alpha_{\mathrm{H}, \mathrm{N} 1}} \mathrm{O}_{\alpha_{\mathrm{O}, \mathrm{N} 1} / 16} \mathrm{~N}_{\alpha_{\mathrm{N}, \mathrm{N} 1} / 14}$ $\mathrm{P}_{\alpha_{\mathrm{P}, \mathrm{N} 1} / 31}$.

- $X_{\mathrm{N} 2}$ : Organisms oxidising nitrite to nitrate: $\mathrm{C}_{\alpha_{\mathrm{C}, \mathrm{N} 2} / 12} \mathrm{H}_{\alpha_{\mathrm{H}, \mathrm{N} 2}} \mathrm{O}_{\alpha_{\mathrm{O}, \mathrm{N} 2} / 16} \mathrm{~N}_{\alpha_{\mathrm{N}, \mathrm{N} 2} / 14}$ $\mathrm{P}_{\alpha, \mathrm{N} 2} / 31$.

- $X_{\mathrm{ALG}}$ : Algae and macrophytes: $\mathrm{C}_{\alpha_{\mathrm{C}, \mathrm{ALG}} / 12} \mathrm{H}_{\alpha_{\mathrm{H}, \mathrm{ALG}}} \mathrm{O}_{\alpha_{\mathrm{O}, \mathrm{ALG}} / 16} \mathrm{~N}_{\alpha_{\mathrm{N}, \mathrm{ALG}} / 14} \mathrm{P}_{\alpha_{\mathrm{P}, \mathrm{ALG}} / 31}$. In the model only one class of algae and macrophytes is introduced. A model extension to more classes can be made easily if this seems to be appropriate.

- $X_{\mathrm{CON}}$ : Consumers: $\mathrm{C}_{\alpha_{\mathrm{C}, \mathrm{CON}} / 12} \mathrm{H}_{\alpha_{\mathrm{H}, \mathrm{CON}}} \mathrm{O}_{\alpha_{\mathrm{O}, \mathrm{CON}} / 16} \mathrm{~N}_{\alpha_{\mathrm{N}, \mathrm{CON}} / 14} \mathrm{P}_{\alpha_{\mathrm{P}, \mathrm{CON} / 31}}$. In the model only one class of consumers is introduced that feeds on algae, heterotrophic and autotrophic organisms and biodegradable particulate organic matter. A model extension to more consumer classes can be made easily.

- $X_{\mathrm{S}}$ : Particulate organic material, assumed to be available for biodegradation after hydrolysis: $\mathrm{C}_{\alpha_{\mathrm{C}, \mathrm{XS}} / 12} \mathrm{H}_{\alpha_{\mathrm{H}, \mathrm{XS}}} \mathrm{O}_{\alpha_{\mathrm{O}, \mathrm{XS} / 16}} \mathrm{~N}_{\alpha_{\mathrm{N}, \mathrm{XS}} / 14} \mathrm{P}_{\alpha_{\mathrm{P}, \mathrm{XS} / 31}}$. These substances must undergo hydrolysis catalysed by heterotrophic organisms before being directly degradable.

- $X_{\mathrm{I}}$ : Inert particulate organic material: $\mathrm{C}_{\alpha_{\mathrm{C}, \mathrm{XI}} / 12} \mathrm{H}_{\alpha_{\mathrm{H}, \mathrm{XI}}} \mathrm{O}_{\alpha_{\mathrm{O}, \mathrm{XI}} / 16} \mathrm{~N}_{\alpha_{\mathrm{N}, \mathrm{XI}} / 14} \mathrm{P}_{\alpha_{\mathrm{P}, \mathrm{XI}} / 31}$. These substances are assumed to be not biodegradable within the time frame of relevance.

- $X_{\mathrm{P}}$ : Phosphate adsorbed to particles. For stoichiometric calculations assumed to be $\mathrm{HPO}_{4}^{2-}-\mathrm{P}$. 
- $X_{\mathrm{II}}$ : Particulate inorganic material. In the basic model, particulate inorganic material is summarised in one class. However, an extension to classes of different size or composition can easily be made.

\section{Measurability of model components}

One of the issues in any modelling exercise is the necessity to provide data for the model variables. Preferably standard laboratory methods should be applied. In this section, we relate the different state variables of the proposed model to measured quantities such as COD, BOD, TOC, suspended solids, Kjeldahl nitrogen, dry mass, and element analyses. Both total and filtered samples are presumed to be available. Note again that the equations given in this section are only good approximations if other elements than $\mathrm{C}, \mathrm{H}, \mathrm{O}, \mathrm{N}$ and $\mathrm{P}$ do not contribute significantly to dry weight (this may not be true in an activated sludge plant with chemical precipitation).

Straightforward direct analysis can be performed for the following variables: $S_{\mathrm{NH} 3}+$ $S_{\mathrm{NH} 4}, S_{\mathrm{NO} 2}, S_{\mathrm{NO} 3}, S_{\mathrm{HPO} 4}+S_{\mathrm{H} 2 \mathrm{PO} 4}, S_{\mathrm{O} 2}, S_{\mathrm{Ca}}$, and $S_{\mathrm{H}}$, the latter being $10^{-\mathrm{pH}}$. The sum of $S_{\mathrm{CO} 2}$ and $S_{\mathrm{HCO} 3}$ can be obtained from either a TIC (total inorganic carbon) analysis or an advanced alkalinity titration. Using the $\mathrm{pH}$ value subsequently allows differentiation between $S_{\mathrm{CO} 2}$ and $S_{\mathrm{HCO} 3}, S_{\mathrm{NH} 4}$ and $S_{\mathrm{NH} 3}$, and $S_{\mathrm{H} 2 \mathrm{PO} 4}$ and $S_{\mathrm{HPO} 4}$.

More problems exist with the determination of the multitude of organic substances of the model. However, overall measurement is an important starting point for the assessment of the different fractions. First, an overall COD analysis (cf. Eq. 5 for a definition of COD) of the total and filtered samples allows differentiation between dissolved and particulate fractions, i.e.

$$
\begin{aligned}
& \mathrm{COD}_{\text {tot }}=\mathrm{COD} \text { of }\left(S_{\mathrm{S}}+S_{\mathrm{I}}+X_{\mathrm{H}}+X_{\mathrm{N} 1}+X_{\mathrm{N} 2}+X_{\mathrm{ALG}}+X_{\mathrm{CON}}+X_{\mathrm{S}}+X_{\mathrm{I}}\right) \\
& \mathrm{COD}_{\text {diss }}=\mathrm{COD} \text { of }\left(S_{\mathrm{S}}+S_{\mathrm{I}}\right), \quad \mathrm{COD}_{\text {part }}=\mathrm{COD}_{\text {tot }}-\mathrm{COD}_{\text {diss }}
\end{aligned}
$$

Differentiating between $S_{\mathrm{S}}$ and $S_{\mathrm{I}}$ can proceed via the analysis of the biodegradable part of the dissolved organic fraction, i.e. via a type of BOD analysis of the filtered sample (at the appropriate time scale). A similar experiment can be performed on the complete sample. By combining both results, the inert particulate fraction $X_{\mathrm{I}}$ can be assessed (Lesouef et al., 1992).

Organic substances can be analysed for their C, N, P, O, and $\mathrm{H}$ content. This leads to TOC (total organic carbon), DOC (dissolved organic carbon), PON, DON, POP, DOP, $\mathrm{POH}$, and $\mathrm{DOH}$ :

$$
\begin{aligned}
\mathrm{TOC}= & \alpha_{\mathrm{C}, \mathrm{SS}} S_{\mathrm{S}}+\alpha_{\mathrm{C}, \mathrm{SI}}+S_{\mathrm{I}}+\alpha_{\mathrm{C}, \mathrm{XH}} X_{\mathrm{H}}+\alpha_{\mathrm{C}, \mathrm{XNI}} X_{\mathrm{N} 1}+\alpha_{\mathrm{C}, \mathrm{N} 2} X_{\mathrm{N} 2}+\alpha_{\mathrm{C}}, \mathrm{X}_{\mathrm{ALG}}+\alpha_{\mathrm{C}, \mathrm{CON}} X_{\mathrm{CON}} \\
& +\alpha_{\mathrm{C}, \mathrm{XS}} X_{\mathrm{S}}+\alpha_{\mathrm{C}, \mathrm{XI}} X_{\mathrm{I}} \\
\text { DOC }= & \alpha_{\mathrm{C}, \mathrm{SS}} S_{\mathrm{S}}+\alpha_{\mathrm{C}, \mathrm{SI}}+S_{\mathrm{I}} .
\end{aligned}
$$

where equivalent expressions apply to $\mathrm{N}, \mathrm{P}, \mathrm{O}$, and $\mathrm{H}$. Note that total and dissolved Kjeldahl-nitrogen are

$\mathrm{KN}_{\text {tot }}=\mathrm{TON}+\mathrm{S}_{\mathrm{NH} 4}+\mathrm{S}_{\mathrm{NH} 3}, \quad \mathrm{KN}_{\text {diss }}=\mathrm{DON}+S_{\mathrm{NH} 4}+S_{\mathrm{NH} 3}$

and total phosphorus is

$\mathrm{TP}=\mathrm{TOP}+S_{\mathrm{H} 2 \mathrm{PO}}+S_{\mathrm{HPO} 4}+X_{\mathrm{P}}$

which is useful to check mass balances (Nowak et al., 1999).

Volatile suspended solids determination gives the sum of all organic particulate fractions, summing their carbon, nitrogen, oxygen, and hydrogen content 


$$
\mathrm{VSS}=\sum_{i=\mathrm{H}, \mathrm{N} 1, \mathrm{~N} 2, \mathrm{ALG}, \mathrm{CON}, \mathrm{S}, \mathrm{I}}\left(\alpha_{\mathrm{C}, \mathrm{X} i} X_{i}+\alpha_{\mathrm{H}, \mathrm{X} i} X_{i}+\alpha_{\mathrm{O}, \mathrm{X} i} X_{i}+\alpha_{\mathrm{N}, \mathrm{X} i} X_{i}\right)
$$

and dry mass of organic particles is

$$
\mathrm{OM}=\sum_{i=\mathrm{H}, \mathrm{N} 1, \mathrm{~N} 2, \mathrm{ALG}, \mathrm{CON}, \mathrm{S}, \mathrm{I}} X_{i}
$$

Organism counts are often converted to wet mass units. These can then be converted to dry mass with the aid of an empirical conversion factor (between 0.1 and 0.4 depending on species).

To determine the fractions of samples of particulate organic material is quite problematic. The particulate biodegradable material $X_{\mathrm{S}}$ could be determined via respirometric analysis and an assumed yield coefficient (Vanrolleghem et al., 1999). However, interference with endogenous respiration may occur. Determination of the organism fractions $\left(X_{\mathrm{H}}, X_{\mathrm{N} 1}\right.$, $X_{\mathrm{N} 2}, X_{\mathrm{ALG}}, X_{\mathrm{CON}}$ ) can be based either on activity measurement and a specific activity factor or a specific analysis of some property of the group of organisms (e.g. chlorophyll determination for algae). The activity measurements are COD-oxidation rates, nitrification rates, photosynthesis rates, and reduction of respiration rates in the presence of inhibitors that specifically inhibit certain groups such as nitrifiers or consumers. An alternative method, which has been quite successfully used in wastewater treatment fractionation of biomass, consists of calculating the amount of biomass grown under certain loading conditions using typical yield values and retention times (Vanrolleghem et al., 1999). It can be expected that this approach also works for certain riverine situations.

\section{Biological and chemical conversion processes}

In this section a complete description of the biochemical process equations is given. Note that recommendations for model simplifications are given in Vanrolleghem et al. (2001). In order to apply the model, these biochemical process equations must be supplemented by transport equations, equations for substance transfer between river compartments and to the atmosphere, geometrical conversions between concentrations in the water column and surface densities of sessile organisms, etc.

The qualitative stoichiometric matrix of the model is given in Table 1, the stoichiometric parameters required to make all stoichiometric coefficients unique are listed in Table 2 and the formulations of the process rates are given in Table 3. These definitions make the model stoichiometry unique up to the numerical values of the parameters. Because it is some work to calculate the stoichiometric coefficients from the stoichiometric parameters and from the composition parameters of organic compounds $\left(\alpha_{C}, \alpha_{H}, \alpha_{O}, \alpha_{N}\right.$ and $\alpha_{P}$ for all organic compounds) using conservation principles for the elements and for charge, the equations for the stoichiometric coefficients are given in appendix 1 (two additional state variables, $S_{\mathrm{N} 2}$ and $S_{\mathrm{H} 2 \mathrm{O}}$, for molecular nitrogen gas and for water, respectively, are introduced in the appendix in order to make mass balance checks possible). Furthermore, these formulas are also implemented in a Excel spreadsheet that can be obtained from the authors (http://www.eawag.ch/ reichert). A numerical example is given in appendix 2.

In Table 1, for all stoichiometric coefficients that are not equal to unity, only the signs are given: "+" indicates a positive stoichiometric coefficient, "-" a negative coefficient, "?" indicates a coefficient the sign of which depends on the composition of the organic substances involved in the process and on the stoichiometric parameters, and "(+)" is the same as "?", but in this case, the composition of compounds and the stoichiometric parameters should be chosen in a way that guarantees that this coefficient is non-negative (because there is no limiting factor to the corresponding compound in the process rate). In Table 3, 
limiting terms in square brackets can be omitted if the chosen stoichiometry is such that the corresponding component is not consumed. Stoichiometry and kinetics of processes are briefly discussed in the following paragraph.

The following processes are considered in the model (numbers correspond to rows in Tables 1 and 3):

- (1) Aerobic growth of heterotrophs: Growth of heterotrophic organisms using dissolved organic substrate, dissolved oxygen, and nutrients. If the organic substrate contains enough phosphorus $\left(\alpha_{\mathrm{P}, \mathrm{XH}}<Y_{\mathrm{H}, \mathrm{aer}} \alpha_{\mathrm{P}, \mathrm{SS}}\right)$, no phosphate uptake from the surrounding water is necessary and the limiting term with respect to phosphate can be neglected. If there is not enough nitrogen in the substrate $\left(\alpha_{\mathrm{N}, \mathrm{XH}}>Y_{\mathrm{H}, \mathrm{aer}} \alpha_{\mathrm{N}, \mathrm{SS}}\right)$, ammonia is consumed by process (1a). If ammonia concentrations become very low, there is a switch to the nitrate uptake process (1b). The ammonia limitation term in process (1a) and the whole process (1b) can be omitted if there is enough nitrogen in the substrate $\left(\alpha_{\mathrm{N}, \mathrm{XH}}>\right.$ $Y_{\mathrm{H}, \mathrm{aer}} \alpha_{\mathrm{N}, \mathrm{SS}}$ ). In this case the excess nitrogen is released as ammonia by process ( $1 \mathrm{a}$ ).

- $(2,6,8,10,13)$ Aerobic endogenous respiration: Loss of biomass by aerobic endogenous respiration.

- (3) Anoxic growth of heterotrophs: Growth of heterotrophic organisms with oxygen gained by reducing nitrate to nitrite or nitrite to molecular nitrogen (denitrification; processes 3a and 3b, respectively). If $\alpha_{\mathrm{P}, \mathrm{XH}}<Y_{\mathrm{H}, \mathrm{aer}} \alpha_{\mathrm{P}, \mathrm{SS}}, S_{\mathrm{HPO} 4}$ must be available for growth. In the process rate, the phosphate limitation term (square brackets in Table 3 ) is only present if this condition is fulfilled. This process is inhibited by the presence of dissolved oxygen.

- (4) Anoxic endogenous respiration of heterotrophic organisms: Loss of heterotrophic biomass in the absence of dissolved oxygen by endogenous respiration with nitrate (for simplicity this process is formulated as a one step reduction of nitrate to molecular nitrogen in contrast to anoxic growth).

- (5) Growth of 1 st stage nitrifiers: Growth of organisms that oxidise ammonia to nitrite.

- (7) Growth of 2nd stage nitrifiers: Growth of organisms that oxidise nitrite to nitrate. In order to avoid problems in the absence of ammonia, it is assumed that the nitrogen source for build up of biomass is also nitrite (due to the small contribution to nitrite consumption this assumption is not important).

- (9) Growth of algae: Growth of algae by primary production. This process is divided into two subprocesses describing growth with ammonia (preferred) or nitrate as the nitrogen source. The Steele function is used to describe light limitation and light inhibition.

- $(11,14)$ Death of algae or consumers: Conversion of algae or consumers to slowly degradable and inert organic matter by death, lysis, etc. At the simplification level of this model, which uses a constant composition of organic substances for each class, death of algae and consumers is difficult to describe. This is because dead organic material may have a composition other than algae or consumers. This problem is solved with the introduction of a yield coefficient for the death process that is used to make mass conservation of all elements possible without requiring an uptake of oxygen, nitrogen, phosphorus or carbon during the death process. The disadvantage of this concept is that, depending on differences in the composition of algae and particulate organic matter, the process may release oxygen, ammonia, phosphate and carbon dioxide. If there is not strong evidence for different composition of different classes of organic material, this problem can be solved by using the same composition for algae, consumers and dead organic substances and setting these yield coefficients to unity.

- (12) Growth of consumers: Growth of consumers by grazing on algae, on particulate organic matter and on heterotrophic and autotrophic organisms (subprocesses 12a and 
Table 1 Qualitative stoichiometric matrix of the complete river water quality model no. 1 (cf. Vanrolleghemet al., 2001 for hints for model simplifications)

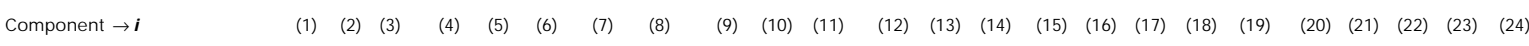

j Process $\downarrow$

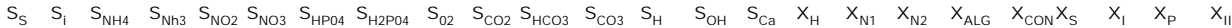

\begin{tabular}{|c|c|c|c|c|c|c|c|c|c|c|c|c|c|c|c|c|c|c|c|c|}
\hline (1a) & $\begin{array}{l}\text { Aerobic growth of } \\
\text { heterotrophs with } \mathrm{NH}_{4}\end{array}$ & - & $?$ & & & & $?$ & & - & + & & & $?$ & & 1 & & & & & \\
\hline (1b) & $\begin{array}{l}\text { Aerobic growth of } \\
\text { heterotrophs with } \mathrm{NO}_{3}\end{array}$ & - & & & & - & ? & & - & + & & & ? & & 1 & & & & & \\
\hline (2) & Aerobic resp. of het. & & + & & & & + & & - & + & & & - & & -1 & & & & & + \\
\hline (3a) & $\begin{array}{l}\text { Anoxic growth of } \\
\text { heterotrophs with } \mathrm{NO}_{3}\end{array}$ & - & & & + & - & $?$ & & & + & & & ? & & 1 & & & & & \\
\hline (3b) & $\begin{array}{l}\text { Anoxic growth of } \\
\text { heterotrophs with } \mathrm{NO}_{2}\end{array}$ & - & & & - & & ? & & & + & & & ? & & 1 & & & & & \\
\hline (4) & Anoxic resp. of het. & & + & & & - & + & & & + & & & - & & -1 & & & & & + \\
\hline (5) & $\begin{array}{l}\text { Growth of 1st-stage } \\
\text { nitrifiers }\end{array}$ & & - & & + & & - & & - & - & & & + & & & 1 & & & & \\
\hline (6) & $\begin{array}{l}\text { Aerobic respiration of } \\
\text { 1st-stage nitrifiers }\end{array}$ & & + & & & & + & & - & + & & & - & & & -1 & & & & + \\
\hline (7) & $\begin{array}{l}\text { G rowth of 2nd-stage } \\
\text { nitriflers }\end{array}$ & & & & - & + & - & & - & - & & & - & & & 1 & $\mathrm{~L}$ & & & \\
\hline (8) & $\begin{array}{l}\text { Aerobic respiration of } \\
2 \text { nd-stage nitrifiers }\end{array}$ & & + & & & & + & & - & + & & & - & & & & -1 & & & + \\
\hline (9a) & G rowth of algae with $\mathrm{NH}_{4}$ & & - & & & & - & & + & - & & & - & & & & 1 & & & \\
\hline (9b) & G rowth of algae with $\mathrm{NO}_{3}$ & & & & & - & - & & + & - & & & - & & & & 1 & & & \\
\hline (10) & Aerobic resp. of algae & & + & & & & + & & - & + & & & - & & & & -1 & & & + \\
\hline (11) & Death of algae & & $(+)$ & & & & $(+)$ & & $(+)$ & $?$ & & & ? & & & & -1 & & + & + \\
\hline (12a) & G rowth of cons. on $x_{\mathrm{ALG}}$ & & $(+)$ & & & & $(+)$ & & - & $?$ & & & ? & & & & - & 1 & + & \\
\hline (12b) & Growth of cons. on $x_{S}$ & & $(+)$ & & & & $(+)$ & & - & ? & & & ? & & & & & 1 & - & \\
\hline (12c) & Growth of cons. on $X_{H}$ & & $(+)$ & & & & $(+)$ & & - & $?$ & & & ? & & - & & & 1 & & \\
\hline (12d) & Growth of cons. on $x_{N 1}$ & & $(+)$ & & & & $(+)$ & & - & $?$ & & & ? & & & - & & 1 & & \\
\hline (12e) & Growth of cons. on $x_{\mathrm{N} 2}$ & & $(+)$ & & & & $(+)$ & & - & $?$ & & & ? & & & - & & 1 & & \\
\hline (13) & Aerobic resp. of cons. & & + & & & & + & & - & + & & & - & & & & & -1 & & + \\
\hline (14) & Death of consumers & & $(+)$ & & & & $(+)$ & & $(+)$ & $?$ & & & $?$ & & & & & -1 & + & + \\
\hline (15) & Hydrolysis & + & $(+)$ & & & & $(+)$ & & $(+)$ & ? & & & ? & & & & & & -1 & \\
\hline (16) & Eq. $\mathrm{CO}_{2} \leftrightarrow \mathrm{HCO}_{3}$ & & & & & & & & & -1 & 1 & & + & & & & & & & \\
\hline (17) & Eq. $\mathrm{HCO}_{3} \leftrightarrow \mathrm{CO}_{3}$ & & & & & & & & & & -1 & 1 & + & & & & & & & \\
\hline (18) & Eq. $\mathrm{H}_{2} \mathrm{O} \leftrightarrow \mathrm{H}^{+} \mathrm{OH}$ & & & & & & & & & & & & 1 & 1 & & & & & & \\
\hline (19) & Eq. $\mathrm{NH}_{4} \leftrightarrow \mathrm{NH}_{3}$ & & -1 & 1 & & & & & & & & & + & & & & & & & \\
\hline (20) & Eq. $\mathrm{H}_{2} \mathrm{PO}_{4} \leftrightarrow \mathrm{HPO}_{4}$ & & & & & & 1 & -1 & & & & & + & & & & & & & \\
\hline (21) & Eq. $\mathrm{Ca} \leftrightarrow \mathrm{CO}_{3}$ & & & & & & & & & & & + & & 1 & & & & & & \\
\hline (22) & Ads. of phosphate & & & & & & -1 & & & & & & & & & & & & & 1 \\
\hline (23) & Des. of phosphate & & & & & & 1 & & & & & & & & & & & & & -1 \\
\hline
\end{tabular}




\begin{tabular}{|c|c|c|}
\hline Symbol & Description & Unit \\
\hline$Y_{H, \text { aer }}$ & Yield for aerobic heterotrophic growth & $g X_{H} / g S_{S}$ \\
\hline$Y_{H, \text { anox,NO3 }}$ & Yield for anoxic heterotrophic growth with nitrate & $g X_{H} / g S_{S}$ \\
\hline $\mathrm{Y}_{\mathrm{H}, \mathrm{anox}, \mathrm{NO} 2}$ & Yield for anoxic heterotrophic growth with nitrite & $g X_{H} / g S_{S}$ \\
\hline$f_{I, B A C}$ & $\begin{array}{l}\text { Fraction of respired heterotrophic and autotrophic biomass } \\
\text { that becomes inert }\end{array}$ & $g X_{l} / g X_{H}$ \\
\hline $\mathrm{Y}_{\mathrm{N} 1}$ & Yield for growth of 1st step nitrifiers & $g X_{N 1} / g S_{N H 4}-\mathrm{N}$ \\
\hline $\mathrm{Y}_{\mathrm{N} 2}$ & Yield for growth of 2 nd step nitrifiers & $\mathrm{gX}_{\mathrm{N} 2} / \mathrm{gS}_{\mathrm{NO2}}-\mathrm{N}$ \\
\hline$f_{I, A L G}$ & $\begin{array}{l}\text { F raction of particulate organic matter that becomes inert } \\
\text { during death of algae }\end{array}$ & $g X_{1} / g\left(X_{S}+X_{1}\right)$ \\
\hline$Y_{A L G \text {, death }}$ & $\begin{array}{l}\text { Yield for death of algae (set to a value that avoids consumption } \\
\text { of nutrients and oxygen) }\end{array}$ & $g\left(X_{S}+X_{I}\right) / g X_{A L G}$ \\
\hline$Y_{\text {CON }}$ & $\begin{array}{l}\text { Yield for grazing (set to a value that avoids consumption } \\
\text { of nutrients and oxygen) }\end{array}$ & $g X_{C O N} / g X_{A L G}$ \\
\hline$f_{e}$ & Fraction of incorporated biomass that is excreted as fecal pellets & $g X_{S} / g X_{C O N}$ \\
\hline$f_{I, C O N}$ & $\begin{array}{l}\text { Fraction of particulate organic matter that becomes inert during } \\
\text { death of consumers }\end{array}$ & $g X_{l} / g\left(X_{S}+X_{l}\right)$ \\
\hline$Y_{C O N \text {, death }}$ & $\begin{array}{l}\text { Y ield for death of consumers (set to a value that avoids } \\
\text { consumption of nutrients and oxygen) }\end{array}$ & $g\left(X_{S}+X_{I}\right) / g X_{C O N}$ \\
\hline$Y_{H Y D}$ & $\begin{array}{l}\text { Yield for hydrolysis (set to a value that avoids consumption } \\
\text { of nutrients and oxygen) }\end{array}$ & $g_{S} / g X_{S}$ \\
\hline
\end{tabular}

$12 \mathrm{e}$, respectively) with production of fecal pellets in the form of slowly biodegradable particulate organic matter. It is assumed that organic matter is homogeneously distributed. Note that this assumption may be violated for sessile organisms. A simple way to consider this fact is discussed in Reichert (2001). The yield coefficient must be small enough to guarantee the availability of enough nitrogen and phosphorus in the food for building consumer biomass. A very simple process rate proportional to the product of food and consumer concentrations was chosen. In some cases limiting terms with respect to food or consumers may be necessary.

- (15) Hydrolysis: Dissolution of slowly biodegradable particulate organic matter to dissolved organic matter catalysed by heterotrophic biomass. Similarly to the death processes, a yield coefficient is introduced to guarantee that no oxygen, ammonia, or phosphate must be consumed during the hydrolysis process. If there is not strong evidence that the composition of particulate and dissolved organic matter is different, the same composition should be used and the yield coefficient set equal to unity.

- (16-21) Chemical equilibria: Chemical equilibria between $\mathrm{CO}_{2}$ and $\mathrm{HCO}_{3}^{-}$, between $\mathrm{HCO}_{3}^{-}$and $\mathrm{CO}_{3}^{2-}$, between $\mathrm{H}_{2} \mathrm{O}$ and $\mathrm{H}^{+}$and $\mathrm{OH}^{-}$, between $\mathrm{NH}_{4}^{+}$and $\mathrm{NH}_{3}$, between $\mathrm{H}_{2} \mathrm{PO}_{4}^{-}$and $\mathrm{HPO}_{4}^{2-}$, and between $\mathrm{Ca}^{2+}$ and $\mathrm{CO}_{3}^{2-}$ and $\mathrm{CaCO}_{3}(\mathrm{~s})$.

- (22) Adsorption of phosphate: Any type of binding of phosphate on particulate matter.

- (23) Desorption of phosphate: Release of phosphate previously bound on particulate matter.

Note that all process formulations given above are based on in-situ concentrations of substrates and in-situ light conditions. If a biofilm of sessile organisms is modelled without explicit consideration of substrate gradients and light availability, additional limiting factors must be formulated on an empirical basis (for an example of how this can be done see Reichert, 2001). 
Table 3 Process rates (terms in square brackets are omitted under certain circumstances, see text)

$$
\begin{aligned}
& \begin{array}{lll}
\hline \text { No. } & \text { Process } & \text { Rate } \\
\hline \text { (1a) } & \begin{array}{l}
\text { Aerobic growth of } \\
\text { heterotrophs with } \mathrm{NH}_{4}
\end{array} & k_{\text {gro, } \mathrm{H}, \text { aer, } \mathrm{To}} \mathrm{e}^{\beta_{\mathrm{H}}\left(T-T_{0}\right)} \frac{S_{\mathrm{S}}}{K_{\mathrm{S}, \mathrm{H}, \text { aer }}+S_{S}} \frac{S_{\mathrm{O} 2}}{K_{\mathrm{O} 2, \mathrm{H}, \text { aer }}+S_{\mathrm{O} 2}}\left[\frac{S_{\mathrm{NH} 4}+S_{\mathrm{NH} 3}}{K_{\mathrm{N}, \mathrm{H}, \text { aer }}+S_{\mathrm{NH} 4}+S_{\mathrm{NH} 3}}\right]
\end{array} \\
& \times\left[\frac{S_{\mathrm{HPO} 4}+S_{\mathrm{H} 2 \mathrm{PO} 4}}{K_{\mathrm{HPO} 4, \mathrm{H}, \text { aer }}+S_{\mathrm{HPO} 4}+S_{\mathrm{H} 2 \mathrm{PO} 4}}\right] X_{\mathrm{H}} \\
& {\left[\begin{array}{l}
k_{\text {gro, } \mathrm{H}, \text { aer, } \mathrm{To}} \mathrm{e}^{\beta} \mathrm{H}^{\left(T-T_{0}\right)} \frac{S_{\mathrm{S}}}{K_{\mathrm{S}, \mathrm{H}, \text { aer }}+S_{S}} \frac{S_{\mathrm{O} 2}}{K_{\mathrm{O} 2, \mathrm{H}, \text { aer }}+S_{\mathrm{O} 2}} \frac{K_{\mathrm{N}, \mathrm{H}, \text { aer }}}{K_{\mathrm{N}, \mathrm{H}, \text { aer }}+S_{\mathrm{NH} 4}+S_{\mathrm{NH} 3}} \\
\times \frac{S_{\mathrm{NO} 3}}{K_{\mathrm{N}, \mathrm{H}, \text { aer }}+S_{\mathrm{NO} 3}}\left[\frac{S_{\mathrm{HPO} 4}+S_{\mathrm{H} 2 \mathrm{PO} 4}}{K_{\mathrm{HPO} 4, \mathrm{H}, \text { aer }}+S_{\mathrm{HPO} 4}+S_{\mathrm{H} 2 \mathrm{PO} 4}}\right] X_{\mathrm{H}}
\end{array}\right]} \\
& k_{\text {resp, H, aer, To }} \mathrm{e}^{\beta_{\mathrm{H}}\left(T-T_{0}\right)} \frac{S_{\mathrm{O} 2}}{K_{\mathrm{O} 2, \mathrm{H}, \text { aer }}+S_{\mathrm{O} 2}} X_{\mathrm{H}} \\
& k_{\text {gro, } \mathrm{H}, \text { anox, To }} \mathrm{e}^{\beta{ }_{\mathrm{H}}\left(T-T_{0}\right)} \frac{S_{\mathrm{S}}}{K_{\mathrm{S}, \mathrm{H}, \text { anox }}+S_{S}} \frac{K_{\mathrm{O} 2, \mathrm{H}, \text { aer }}}{K_{\mathrm{O} 2, \mathrm{H}, \text { aer }}+S_{\mathrm{O} 2}} \frac{S_{\mathrm{NO} 3}}{K_{\mathrm{NO} 3, \mathrm{H}, \text { anox }}+S_{\mathrm{NO} 3}} \\
& \times\left[\frac{S_{\mathrm{HPO} 4}+S_{\mathrm{H} 2 \mathrm{PO} 4}}{K_{\mathrm{HPO} 4, \mathrm{H}, \text { anox }}+S_{\mathrm{HPO} 4}+S_{\mathrm{H} 2 \mathrm{PO} 4}}\right] X_{\mathrm{H}} \\
& k_{\text {gro, } \mathrm{H}, \text { anox, } \mathrm{To}} \mathrm{e}^{\beta_{\mathrm{H}}\left(T-T_{0}\right)} \frac{S_{\mathrm{S}}}{K_{\mathrm{S}, \mathrm{H}, \text { anox }}+S_{S}} \frac{K_{\mathrm{O} 2, \mathrm{H}, \text { aer }}}{K_{\mathrm{O} 2, \mathrm{H}, \text { aer }}+S_{\mathrm{O} 2}} \frac{S_{\mathrm{NO} 2}}{K_{\mathrm{NO} 2, \mathrm{H}, \text { anox }}+S_{\mathrm{NO} 2}} \\
& \times\left[\frac{S_{\mathrm{HPO} 4}+S_{\mathrm{H} 2 \mathrm{PO} 4}}{K_{\mathrm{HPO} 4, \mathrm{H}, \text { anox }}+S_{\mathrm{HPO} 4}+S_{\mathrm{H} 2 \mathrm{PO} 4}}\right] X_{\mathrm{H}} \\
& k_{\text {resp, } \mathrm{H}, \text { anox, To }} \mathrm{e}^{\beta_{\mathrm{H}}\left(T-T_{0}\right)} \frac{S_{\mathrm{S}}}{K_{\mathrm{O} 2, \mathrm{H}, \text { anox }}+S_{\mathrm{O} 2}} \frac{S_{\mathrm{NO} 3}}{K_{\mathrm{NO} 3, \mathrm{H}, \text { anox }}+S_{\mathrm{NO} 3}} X_{\mathrm{H}} \\
& k_{\text {gro, N1, anox, } \mathrm{To}} \mathrm{e}^{\beta_{\mathrm{N} 1}\left(T-T_{0}\right)} \frac{S_{\mathrm{O} 2}}{K_{\mathrm{O} 2, \mathrm{~N} 1}+S_{\mathrm{O} 2}} \frac{S_{\mathrm{NH} 4}+S_{\mathrm{NH} 3}}{K_{\mathrm{NH} 4, \mathrm{~N} 1}+S_{\mathrm{NH} 4}+S_{\mathrm{NH} 3}} \\
& \times \frac{S_{\mathrm{HPO} 4}+S_{\mathrm{H} 2 \mathrm{PO} 4}}{K_{\mathrm{HPO} 4, \mathrm{~N} 1}+S_{\mathrm{HPO} 4}+S_{\mathrm{H} 2 \mathrm{PO} 4}} X_{\mathrm{N} 1} \\
& \text { nitrifiers } \quad k_{\text {resp, N1, To }} e^{\beta{ }^{N 1}\left(T-T_{0}\right)} \frac{S_{\mathrm{O} 2}}{K_{\mathrm{O} 2, \mathrm{~N} 1}+S_{\mathrm{O} 2}} X_{\mathrm{N} 1} \\
& k_{\text {gro, } \mathrm{N} 2, \text { anox, } \mathrm{To}} \mathrm{e}^{\beta \beta_{\mathrm{N} 2}\left(T-T_{0}\right)} \frac{S_{\mathrm{O} 2}}{K_{\mathrm{O} 2, \mathrm{~N} 2}+S_{\mathrm{O} 2}} \frac{S_{\mathrm{NO} 2}}{K_{\mathrm{NO} 2, \mathrm{~N} 2}+S_{\mathrm{NO} 2}} \\
& \times \frac{S_{\mathrm{HPO} 4}+S_{\mathrm{H} 2 \mathrm{PO} 4}}{K_{\mathrm{HPO} 4, \mathrm{~N} 2}+S_{\mathrm{HPO} 4}+S_{\mathrm{H} 2 \mathrm{PO} 4}} X_{\mathrm{N} 2}
\end{aligned}
$$

(9a) Growth of algae with $\mathrm{NH}_{4}$

$$
\begin{aligned}
k_{\text {gro, } \mathrm{ALG}, \mathrm{To}} \mathrm{e}^{\beta} \mathrm{ALG}^{\left(T-T_{0}\right)} \frac{S_{\mathrm{NH} 4}+S_{\mathrm{NH} 3}+S_{\mathrm{NO} 3}}{K_{\mathrm{N}, \mathrm{ALG}}+S_{\mathrm{NH} 4}+S_{\mathrm{NH} 3}+S_{\mathrm{NO} 3}} \frac{S_{\mathrm{NH} 4}+S_{\mathrm{NH} 3}}{K_{\mathrm{N}, \mathrm{ALG}}+S_{\mathrm{NH} 4}+S_{\mathrm{NH} 3}} \\
\times \frac{S_{\mathrm{HPO} 4}+S_{\mathrm{H} 2 \mathrm{PO} 4}}{K_{\mathrm{HPO} 4, \mathrm{ALG}}+S_{\mathrm{HPO} 4}+S_{\mathrm{H} 2 \mathrm{PO} 4}} \frac{I}{K_{\mathrm{I}}} \exp \left(1-\frac{I}{K_{\mathrm{I}}}\right) X_{\mathrm{ALG}}
\end{aligned}
$$

(9b) G rowth of algae with $\mathrm{NO}_{3}$

$$
\begin{gathered}
k_{\text {gro, } \mathrm{ALG}, \mathrm{To}} \mathrm{e}^{\beta} \mathrm{ALG}^{\left(T-T_{0}\right)} \frac{S_{\mathrm{NH} 4}+S_{\mathrm{NH} 3}+S_{\mathrm{NO} 3}}{K_{\mathrm{N}, \mathrm{ALG}}+S_{\mathrm{NH} 4}+S_{\mathrm{NH} 3}+S_{\mathrm{NO} 3}} \frac{K_{\mathrm{NH} 4, \mathrm{ALG}}}{K_{\mathrm{NH} 4, \mathrm{ALG}}+S_{\mathrm{NH} 4}+S_{\mathrm{NH} 3}} \\
\times \frac{S_{\mathrm{HPO} 4}+S_{\mathrm{H} 2 \mathrm{PO} 4}}{K_{\mathrm{HPO} 4, \mathrm{ALG}}+S_{\mathrm{HPO} 4}+S_{\mathrm{H} 2 \mathrm{PO} 4}} \frac{I}{K_{\mathrm{I}}} \exp \left(1-\frac{I}{K_{\mathrm{I}}}\right) X_{\mathrm{ALG}}
\end{gathered}
$$




\begin{tabular}{|c|c|c|}
\hline No. & Process & Rate \\
\hline (10) & $\begin{array}{l}\text { Aerobic endogenous } \\
\text { respiration of algae }\end{array}$ & $k_{\text {resp, ALG, To }} \mathrm{e}^{\beta_{\mathrm{ALG}}\left(T-T_{0}\right)} \frac{S_{\mathrm{O} 2}}{K_{\mathrm{O} 2, \mathrm{ALG}}+S_{\mathrm{O} 2}} X_{\mathrm{ALG}}$ \\
\hline (11) & Death of algae & $k_{\text {death, ALG, To }} \mathrm{e}^{\beta} \mathrm{ALG}^{\left(T-T_{0}\right)} X_{\mathrm{ALG}}$ \\
\hline$(12 a-e)$ & $\begin{array}{l}\text { G rowth of } C \text { onsumers on } X_{i} \\
i=A L G, S, H, N 1, N 2\end{array}$ & 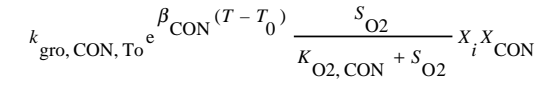 \\
\hline (13) & Aerobic end. resp. of consumers & $k_{\text {resp }, \mathrm{CON}, \mathrm{To}} \mathrm{e}^{\beta \mathrm{CON}^{\left(T-T_{0}\right)}} \frac{S_{\mathrm{O} 2}}{K_{\mathrm{O} 2, \mathrm{CON}}+S_{\mathrm{O} 2}} X_{\mathrm{CON}}$ \\
\hline (14) & Death of consumers & 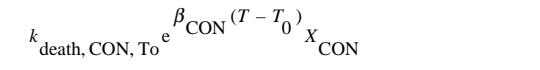 \\
\hline (15) & Hydrolysis & $k_{\text {hyd, To }} \mathrm{e}^{\beta_{\text {hyd }}\left(T-T_{0}\right)} X_{\mathrm{S}}$ \\
\hline (16) & $\mathrm{Eq} \cdot \mathrm{CO}_{2}-\mathrm{HCO}_{3}^{-}$ & $k_{\mathrm{eq}, 1}\left(S_{\mathrm{CO} 2}-S_{\mathrm{H}} S_{\mathrm{HCO} 3} / K_{\mathrm{eq}, 1}\right)$ \\
\hline (17) & Eq. $\mathrm{HCO}_{3}^{-}-\mathrm{CO}_{3}^{2-}$ & $k_{\mathrm{eq}, 2}\left(S_{\mathrm{HCO} 3}-S_{\mathrm{H}} S_{\mathrm{CO} 3} / K_{\mathrm{eq}, 2}\right)$ \\
\hline (18) & $\mathrm{Eq} \cdot \mathrm{H}^{+}-\mathrm{OH}^{-}$ & $k_{\text {eq, w }}\left(1-S_{\mathrm{H}} S_{\mathrm{OH}} / K_{\text {eq, w }}\right)$ \\
\hline (19) & Eq. $\mathrm{NH}_{4}^{+}-\mathrm{NH}_{3}$ & $k_{\text {eq, } \mathrm{N}}\left(S_{\mathrm{NH} 4}-S_{\mathrm{H}} S_{\mathrm{NH} 3} / K_{\text {eq, } \mathrm{N}}\right)$ \\
\hline (20) & $\mathrm{Eq} \cdot \mathrm{H}_{2} \mathrm{PO}_{4}-\mathrm{HPO}_{4}^{2-}$ & $k_{\text {eq, }}\left(S_{\mathrm{H} 2 \mathrm{PO} 4}-S_{\mathrm{H}} S_{\mathrm{HPO} 4} / K_{\text {eq, }}\right)$ \\
\hline (21) & Eq. $\mathrm{Ca}^{2+}-\mathrm{CO}_{3}^{2-}$ & $k_{\text {eq, } \mathrm{s} 0}\left(1-S_{\mathrm{Ca}} S_{\mathrm{CO} 3} / K_{\text {eq, } \mathrm{s} 0}\right)$ \\
\hline (22) & Ads. of phosphate & $k_{a d s} S_{\mathrm{HPO} 4}$ \\
\hline (23) & Des. of phosphate & ${ }^{k}{ }_{\text {des }} X_{\mathrm{P}}$ \\
\hline
\end{tabular}

\section{Summary and conclusions}

The biochemical conversion model for river water quality modelling presented in this paper is rather complex. Special emphasis was given on a rigorous formulation of the mass balances of all considered elements. Although this approach introduces parameters that may not be identifiable in all applications, it clarifies model assumptions and can be the base for a thorough identifiability analysis. Two important reasons for the complexity of the model are the consideration of a rather complete set of processes that may be important under aerobic and anoxic conditions and the inclusion of inorganic carbon compounds for the calculation of $\mathrm{pH}$. In specific applications, however, it may be possible to omit many of these processes. For this reason, in the succeeding paper (Vanrolleghem et al., 2001) recommendations are given for the selection of adequate submodels for specific applications. It is important to study the possibilities for such model simplifications very carefully before an unnecessarily complicated and non-identifiable model is applied. Nevertheless, because different applications entail different components and processes, it is useful to document the full model as it is done in this paper.

\section{Appendix 1: formulas for stoichiometric coefficients}

The following Table 4 contains the formulas for calculating the stoichiometric coefficients from mass fractions of the organic compounds and stoichiometric parameters as described in the paper. These formulas are also implemented in a MS Excel spreadsheet that can be obtained from the authors. The stoichiometric coefficients have been calculated from mass balances of $\mathrm{C}, \mathrm{H}, \mathrm{O}, \mathrm{N}, \mathrm{P}$ and charge. In order to make a check of mass balances possible, the additional state variables $S_{\mathrm{H} 2 \mathrm{O}}$ (water) and $S_{\mathrm{N} 2}$ (nitrogen gas) are introduced. 
(1a) Aerobic growth of heterotrophs with $\mathrm{NH}_{4}$ :

$S_{\mathrm{S}}-\frac{1}{Y_{\mathrm{H}, \mathrm{aer}}}$ $\mathrm{g} S_{\mathrm{S}} / \mathrm{g} X_{\mathrm{H}}$

$S_{\mathrm{NH} 4} \frac{\alpha_{\mathrm{N}, \mathrm{SS}}}{Y_{\mathrm{H}, \text { aer }}}-\alpha_{\mathrm{N}, \mathrm{XH}}$ $\mathrm{g} N / \mathrm{g} X_{\mathrm{H}}$

$S_{\mathrm{HPO} 4} \frac{\alpha_{P, \mathrm{SS}}}{Y_{\mathrm{H}, \text { aer }}}-\alpha_{P, \mathrm{XH}}$ $\mathrm{g} P / \mathrm{g} X_{\mathrm{H}}$

$S_{\mathrm{O} 2}\left(\frac{\alpha_{\mathrm{O}, \mathrm{SS}}}{Y_{\mathrm{H}, \text { aer }}}-\alpha_{\mathrm{O}, \mathrm{XH}}\right)-8\left(\frac{\alpha_{\mathrm{H}, \mathrm{SS}}}{Y_{\mathrm{H}, \text { aer }}}-\alpha_{\mathrm{H}, \mathrm{XH}}\right)-\frac{8}{3}\left(\frac{\alpha_{\mathrm{C}, \mathrm{SS}}}{Y_{\mathrm{H}, \text { aer }}}-\alpha_{\mathrm{C}, \mathrm{XH}}\right)$ $+\frac{12}{7}\left(\frac{\alpha_{\mathrm{N}, \mathrm{SS}}}{Y_{\mathrm{H}, \text { aer }}}-\alpha_{\mathrm{N}, \mathrm{XH}}\right)-\frac{40}{31}\left(\frac{\alpha_{\mathrm{P}, \mathrm{SS}}}{Y_{\mathrm{H}, \text { aer }}}-\alpha_{\mathrm{P}, \mathrm{XH}}\right)$ $\mathrm{g} O / \mathrm{g} X_{\mathrm{H}}$

$S_{\mathrm{CO} 2} \frac{\alpha_{C, \mathrm{SS}}}{Y_{\mathrm{H}, \mathrm{aer}}}-\alpha_{C, \mathrm{XH}}$ $\mathrm{g} C / \mathrm{g} X_{\mathrm{H}}$

$S_{\mathrm{H}} \quad-\frac{1}{14}\left(\frac{\alpha_{\mathrm{N}, \mathrm{SS}}}{Y_{\mathrm{H}, \text { aer }}}-\alpha_{\mathrm{N}, \mathrm{XH}}\right)+\frac{2}{31}\left(\frac{\alpha_{\mathrm{P}, \mathrm{SS}}}{Y_{\mathrm{H}, \text { aer }}}-\alpha_{\mathrm{P}, \mathrm{XH}}\right)$ molesH / g $X_{\mathrm{H}}$

$S_{\mathrm{H} 2 \mathrm{O}} \quad \frac{1}{2}\left(\frac{\alpha_{\mathrm{H}, \mathrm{SS}}}{Y_{\mathrm{H}, \text { aer }}}-\alpha_{\mathrm{H}, \mathrm{XH}}\right)-\frac{3}{28}\left(\frac{\alpha_{\mathrm{N}, \mathrm{SS}}}{Y_{\mathrm{H}, \text { aer }}}-\alpha_{\mathrm{N}, \mathrm{XH}}\right) S_{\mathrm{H}}$

$$
-\frac{3}{62}\left(\frac{\alpha_{\mathrm{P}, \mathrm{SS}}}{Y_{\mathrm{H}, \mathrm{aer}}}-\alpha_{\mathrm{P}, \mathrm{XH}}\right)
$$

moles $_{2} \mathrm{O} / \mathrm{gX} \mathrm{H}$

$X_{\mathrm{H}} \quad 1$

$\mathrm{g} X_{\mathrm{H}} / \mathrm{g} X_{\mathrm{H}}$

(1b) Aerobic growth of heterotrophs with $\mathrm{NO}_{3}$ :

$S_{\mathrm{S}} \quad-\frac{1}{Y_{\mathrm{H}, \text { aer }}}$

$\mathrm{g} S_{\mathrm{S}} / \mathrm{g} X_{\mathrm{H}}$

$S_{\mathrm{NO} 3} \frac{\alpha_{\mathrm{N}, \mathrm{SS}}}{Y_{\mathrm{H}, \text { aer }}}-\alpha_{\mathrm{N}, \mathrm{XH}}$

$\mathrm{g} N / \mathrm{g} X_{\mathrm{H}}$

$S_{\mathrm{HPO} 4} \frac{\alpha_{P, \mathrm{SS}}}{Y_{\mathrm{H}, \text { aer }}}-\alpha_{P, \mathrm{XH}}$

$\mathrm{g} P / \mathrm{g} X_{\mathrm{H}}$

$S_{\mathrm{O} 2}\left(\frac{\alpha_{\mathrm{O}, \mathrm{SS}}}{Y_{\mathrm{H}, \text { aer }}}-\alpha_{\mathrm{O}, \mathrm{XH}}\right)-8\left(\frac{\alpha_{\mathrm{H}, \mathrm{SS}}}{Y_{\mathrm{H}, \text { aer }}}-\alpha_{\mathrm{H}, \mathrm{XH}}\right)-\frac{8}{3}\left(\frac{\alpha_{\mathrm{C}, \mathrm{SS}}}{Y_{\mathrm{H}, \text { aer }}}-\alpha_{\mathrm{C}, \mathrm{XH}}\right)$

$+\frac{20}{7}\left(\frac{\alpha_{\mathrm{N}, \mathrm{SS}}}{Y_{\mathrm{H}, \text { aer }}}-\alpha_{\mathrm{N}, \mathrm{XH}}\right)-\frac{40}{31}\left(\frac{\alpha_{\mathrm{P}, \mathrm{SS}}}{Y_{\mathrm{H}, \text { aer }}}-\alpha_{\mathrm{P}, \mathrm{XH}}\right)$

$\mathrm{g} O / \mathrm{g} X_{\mathrm{H}}$

$S_{\mathrm{CO} 2} \frac{\alpha_{C, \mathrm{SS}}}{Y_{\mathrm{H}, \text { aer }}}-\alpha_{C, \mathrm{XH}}$

$\mathrm{g} C / \mathrm{g} X_{\mathrm{H}}$

$S_{\mathrm{H}} \quad \frac{1}{14}\left(\frac{\alpha_{\mathrm{N}, \mathrm{SS}}}{Y_{\mathrm{H}, \mathrm{aer}}}-\alpha_{\mathrm{N}, \mathrm{XH}}\right)+\frac{2}{31}\left(\frac{\alpha_{\mathrm{P}, \mathrm{SS}}}{Y_{\mathrm{H}, \mathrm{aer}}}-\alpha_{\mathrm{P}, \mathrm{XH}}\right)$ molesH / g $X_{\mathrm{H}}$

$S_{\mathrm{H} 2 \mathrm{O}} \frac{1}{2}\left(\frac{\alpha_{\mathrm{H}, \mathrm{SS}}}{Y_{\mathrm{H}, \text { aer }}}-\alpha_{\mathrm{H}, \mathrm{XH}}\right)-\frac{1}{28}\left(\frac{\alpha_{\mathrm{N}, \mathrm{SS}}}{Y_{\mathrm{H}, \text { aer }}}-\alpha_{\mathrm{N}, \mathrm{XH}}\right)$

$$
-\frac{3}{62}\left(\frac{\alpha_{\mathrm{P}, \mathrm{SS}}}{Y_{\mathrm{H}, \mathrm{aer}}}-\alpha_{\mathrm{P}, \mathrm{XH}}\right)
$$

moles $\mathrm{H}_{2} \mathrm{O} / \mathrm{gX} \mathrm{H}$ 
$(2,6,8,10,13)$ Aerobic endogenous respiration of $X_{i}(i=\mathrm{H}, \mathrm{N} 1, \mathrm{~N} 2, \mathrm{ALG}, \mathrm{CON})$ :

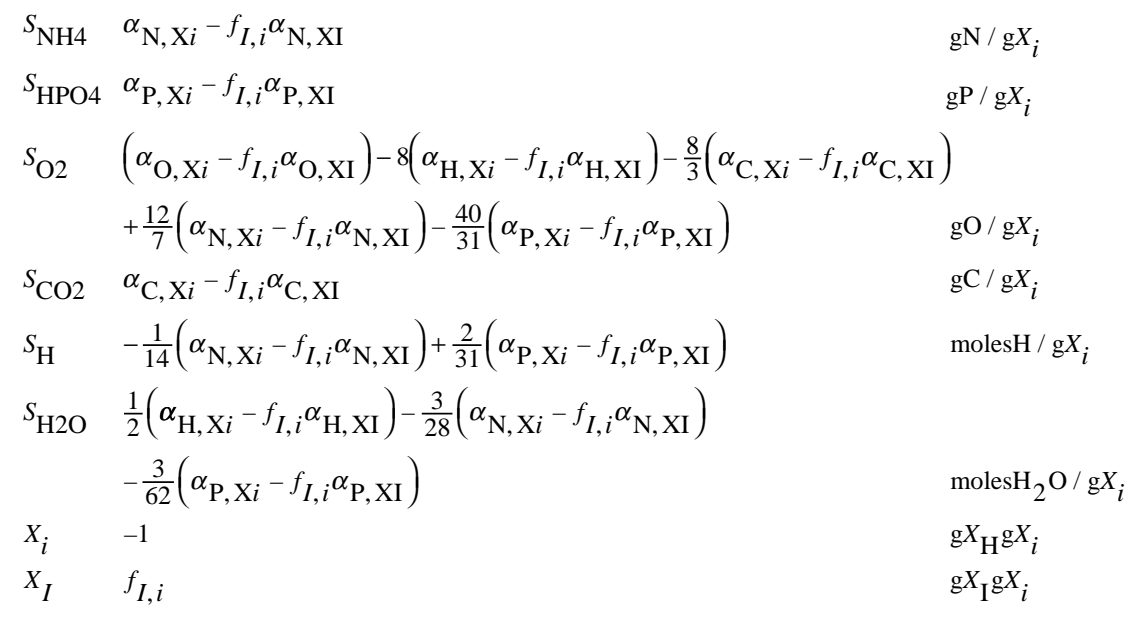

(3a) Aerobic growth of heterotrophs with $\mathrm{NO}_{3}$ :

$S_{\mathrm{S}}-\frac{1}{Y_{\mathrm{H}, \text { anox }}} \quad \mathrm{g} S_{\mathrm{S}} / \mathrm{g} X_{\mathrm{H}}$

$S_{\mathrm{NO} 2}-\frac{7}{8}\left(\frac{\alpha_{\mathrm{O}, \mathrm{SS}}}{Y_{\mathrm{H}, \text { anox }}}-\alpha_{\mathrm{O}, \mathrm{XH}}\right)+7\left(\frac{\alpha_{\mathrm{H}, \mathrm{SS}}}{Y_{\mathrm{H}, \text { anox }}}-\alpha_{\mathrm{H}, \mathrm{XH}}\right)-\frac{7}{3}\left(\frac{\alpha_{\mathrm{C}, \mathrm{SS}}}{Y_{\mathrm{H}, \text { anox }}}-\alpha_{\mathrm{C}, \mathrm{XH}}\right)$ $+\frac{5}{2}\left(\frac{\alpha_{\mathrm{N}, \mathrm{SS}}}{Y_{\mathrm{H}, \text { anox }}}-\alpha_{\mathrm{N}, \mathrm{XH}}\right)-\frac{35}{31}\left(\frac{\alpha_{\mathrm{P}, \mathrm{SS}}}{Y_{\mathrm{H}, \text { anox }}}-\alpha_{\mathrm{P}, \mathrm{XH}}\right) \quad \mathrm{g} N / \mathrm{g} X_{\mathrm{H}}$

$S_{\mathrm{NO} 3} \frac{7}{8}\left(\frac{\alpha_{\mathrm{O}, \mathrm{SS}}}{Y_{\mathrm{H}, \text { anox }}}-\alpha_{\mathrm{O}, \mathrm{XH}}\right)-7\left(\frac{\alpha_{\mathrm{H}, \mathrm{SS}}}{Y_{\mathrm{H}, \text { anox }}}-\alpha_{\mathrm{H}, \mathrm{XH}}\right)-\frac{7}{3}\left(\frac{\alpha_{\mathrm{C}, \mathrm{SS}}}{Y_{\mathrm{H}, \text { anox }}}-\alpha_{\mathrm{C}, \mathrm{XH}}\right)$ $-\frac{3}{2}\left(\frac{\alpha_{\mathrm{N}, \mathrm{SS}}}{Y_{\mathrm{H}, \text { anox }}}-\alpha_{\mathrm{N}, \mathrm{XH}}\right)-\frac{35}{31}\left(\frac{\alpha_{\mathrm{P}, \mathrm{SS}}}{Y_{\mathrm{H}, \text { anox }}}-\alpha \mathrm{P}, \mathrm{XH}\right) \quad \mathrm{gN} / \mathrm{g} X_{\mathrm{H}}$

$S_{\mathrm{HPO} 4} \frac{\alpha_{\mathrm{P}, \mathrm{SS}}}{Y_{\mathrm{H}, \text { anox }}}-\alpha_{\mathrm{P}, \mathrm{XH}}$ $\mathrm{g} P / \mathrm{g} X_{\mathrm{H}}$

$S_{\mathrm{CO} 2} \frac{\alpha_{\mathrm{C}, \mathrm{SS}}}{Y_{\mathrm{H}, \text { anox }}}-\alpha_{\mathrm{C}, \mathrm{XH}}$ $\mathrm{g} C / \mathrm{g} X_{\mathrm{H}}$

$S_{\mathrm{H}} \quad \frac{1}{14}\left(\frac{\alpha_{\mathrm{N}, \mathrm{SS}}}{Y_{\mathrm{H}, \text { anox }}}-\alpha_{\mathrm{N}, \mathrm{XH}}\right)+\frac{2}{31}\left(\frac{\alpha_{\mathrm{P}, \mathrm{SS}}}{Y_{\mathrm{H}, \text { anox }}}-\alpha_{\mathrm{P}, \mathrm{XH}}\right)$ molesH / $\mathrm{gX}_{H}$

$S_{\mathrm{H} 2 \mathrm{O}} \frac{1}{2}\left(\frac{\alpha_{\mathrm{H}, \mathrm{SS}}}{Y_{\mathrm{H}, \text { anox }}}-\alpha_{\mathrm{H}, \mathrm{XH}}\right)+\frac{1}{28}\left(\frac{\alpha_{\mathrm{N}, \mathrm{SS}}}{Y_{\mathrm{H}, \text { anox }}}-\alpha_{\mathrm{N}, \mathrm{XH}}\right)$ $-\frac{3}{62}\left(\frac{\alpha \mathrm{P}, \mathrm{SS}}{Y_{\mathrm{H}, \text { anox }}}-\alpha \mathrm{P}, \mathrm{XH}\right)$ molesH $_{2} \mathrm{O} / \mathrm{gX}_{H}$

$X_{\mathrm{H}} \quad 1$ $\mathrm{g} X_{\mathrm{H}} / \mathrm{g} X_{\mathrm{H}}$

(3b) Aerobic growth of heterotrophs with $\mathrm{NO}_{2}$ :

$S_{\mathrm{S}} \quad-\frac{1}{Y_{\mathrm{H}, \text { anox }}}$ $\mathrm{g} S_{\mathrm{S}} / \mathrm{g} X_{\mathrm{H}}$ 


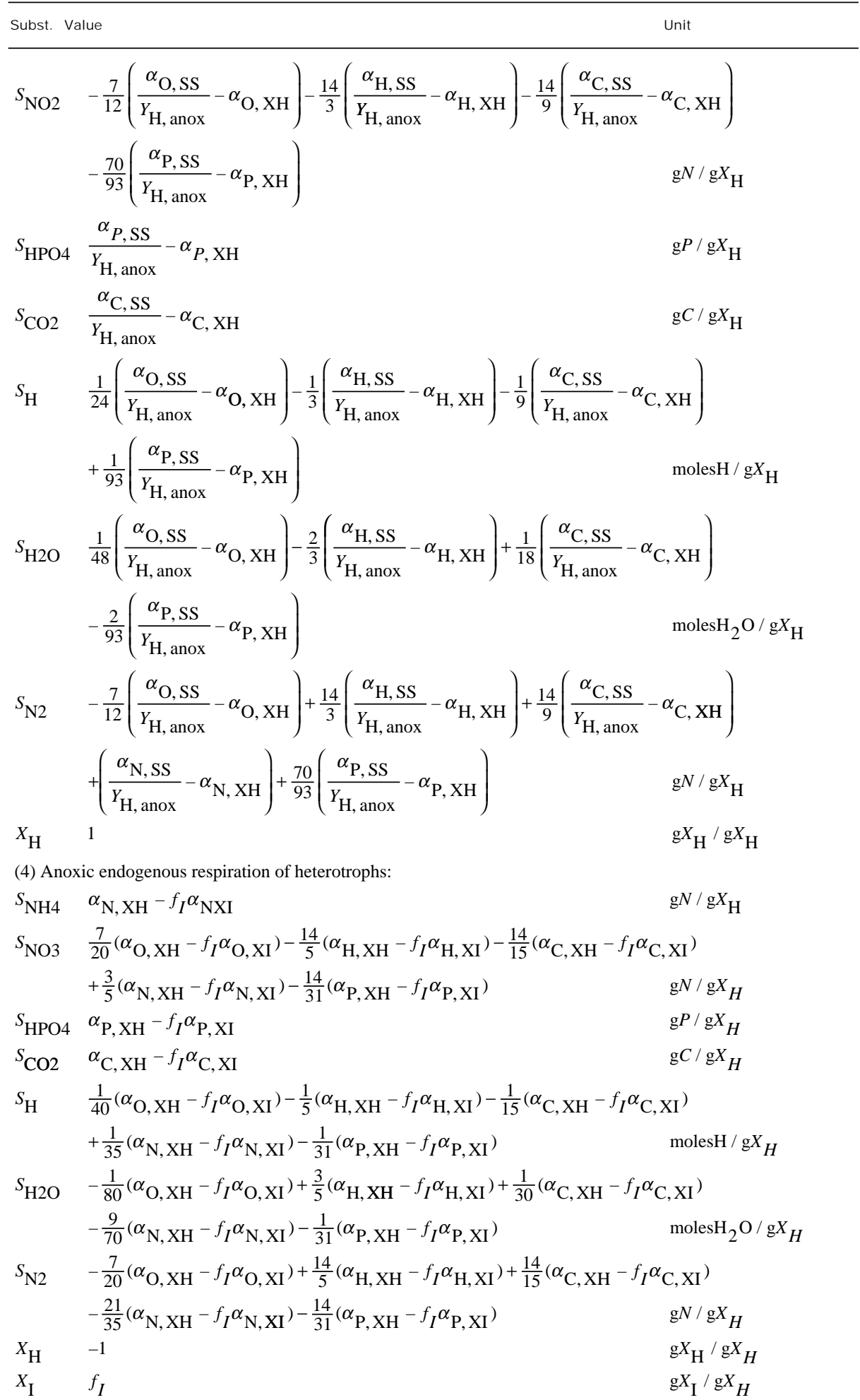


(5) Growth of 1st - stage nitrifiers:

$S_{\mathrm{HPO} 4}{ }^{-\alpha} \mathrm{P}, \mathrm{N} 1$

$S_{\mathrm{NH} 4}-\frac{1}{Y_{\mathrm{N} 1}}$

$\mathrm{g} P / \mathrm{g} X_{\mathrm{N} 1}$

$S_{\mathrm{NO} 2} \frac{1}{Y_{\mathrm{N} 1}}-\alpha_{\mathrm{N}, \mathrm{N} 1}$

$\mathrm{g} N / \mathrm{g} X_{\mathrm{N} 1}$

$\mathrm{g} N / \mathrm{g} X_{\mathrm{N} 1}$

$S_{\mathrm{O} 2}-\frac{24}{7 Y_{\mathrm{N} 1}}+\frac{8 \alpha_{\mathrm{C}, \mathrm{N} 1}}{3}+8 \alpha_{\mathrm{H}, \mathrm{N} 1}-\alpha_{\mathrm{O}, \mathrm{N} 1}+\frac{12 \alpha_{\mathrm{N}, \mathrm{N} 1}}{7}+\frac{40 \alpha_{\mathrm{P}, \mathrm{N} 1}}{31}$

$\mathrm{g} O / \mathrm{g} X_{\mathrm{N} 1}$

$s_{\mathrm{CO} 2}-{ }^{-\alpha} \mathrm{C}, \mathrm{N} 1$

$S_{\mathrm{H}} \frac{2}{14 Y_{\mathrm{N} 1}}-\frac{\alpha_{\mathrm{N}, \mathrm{N} 1}}{14}-\frac{2 \alpha_{\mathrm{P}, \mathrm{N} 1}}{31}$

$\mathrm{g} C / \mathrm{g} X_{\mathrm{N} 1}$

molesH / g $X_{\mathrm{N} 1}$

$S_{\mathrm{H} 2 \mathrm{O}} \frac{1}{14 Y_{\mathrm{N} 1}}-\frac{\alpha_{\mathrm{H}, \mathrm{N} 1}}{2}+\frac{\alpha_{\mathrm{N}, \mathrm{N} 1}}{28}+\frac{3 \alpha_{\mathrm{P}, \mathrm{N} 1}}{62}$

molesH $_{2} O / g X_{\mathrm{N} 1}$

$X_{\mathrm{N} 1} \quad 1$

$\mathrm{g} X_{\mathrm{N} 1} / \mathrm{g} X_{\mathrm{N} 1}$

(7) Growth of 2nd stage nitrifiers:

$S_{\mathrm{NO} 2}-\frac{1}{Y_{\mathrm{N} 2}}$

$\mathrm{g} N / \mathrm{g} X_{\mathrm{N} 2}$

$S_{\mathrm{NO} 3} \frac{1}{Y_{\mathrm{N} 2}}-\alpha_{\mathrm{N}, \mathrm{N} 2}$

$\mathrm{g} N / \mathrm{g} X_{\mathrm{N} 2}$

$S_{\mathrm{HPO} 4}{ }^{-\alpha} \mathrm{P}, \mathrm{N} 2$

$\mathrm{g} P / \mathrm{g} X X_{\mathrm{N} 2}$

$S_{\mathrm{O} 2}-\frac{8}{7 Y_{\mathrm{N} 2}}+\frac{8 \alpha_{\mathrm{C}, \mathrm{N} 2}}{3}+8 \alpha_{\mathrm{H}, \mathrm{N} 2}-\alpha_{\mathrm{O}, \mathrm{N} 2}+\frac{20 \alpha_{\mathrm{N}, \mathrm{N} 2}}{7}+\frac{40 \alpha_{\mathrm{P}, \mathrm{N} 2}}{31}$

$\mathrm{g} O / \mathrm{g} X_{\mathrm{N} 2}$

${ }^{S} \mathrm{CO} 2{ }^{-\alpha} \mathrm{C}, \mathrm{N} 2$

$\mathrm{g} C / \mathrm{g} X_{\mathrm{N} 2}$

$S_{\mathrm{H}} \quad-\frac{\alpha_{\mathrm{N}, \mathrm{N} 2}}{14}-\frac{2 \alpha_{\mathrm{P}, \mathrm{N} 2}}{31}$

molesH / $\mathrm{g} X_{\mathrm{N} 2}$

$S_{\mathrm{H} 2 \mathrm{O}}-\frac{\alpha_{\mathrm{H}, \mathrm{N} 2}}{2}+\frac{\alpha_{\mathrm{N}, \mathrm{N} 2}}{28}+\frac{3 \alpha_{\mathrm{P}, \mathrm{N} 2}}{62}$

molesH $_{2} \mathrm{O} / \mathrm{g} X_{\mathrm{N} 2}$

$X_{\mathrm{N} 2} \quad 1$

$\mathrm{g} X_{\mathrm{N} 2} / \mathrm{g} X_{\mathrm{N} 2}$

(9a) Growth of algae with $\mathrm{NH}_{4}$ :

$S_{\mathrm{NH} 4}-\alpha_{\mathrm{N}, \mathrm{ALG}}$

$\mathrm{g} N / \mathrm{g} X \mathrm{ALG}$

$S_{\mathrm{HPO} 4}{ }^{-\alpha} \mathrm{P}, \mathrm{ALG}$

$\mathrm{g} P / \mathrm{g} X_{\mathrm{ALG}}$

$S_{\mathrm{O} 2} \quad \frac{{ }^{8} \alpha_{\mathrm{C}, \mathrm{ALG}}}{3}+8 \alpha_{\mathrm{H}, \mathrm{ALG}}-\alpha_{\mathrm{O}, \mathrm{ALG}}-\frac{12 \alpha_{\mathrm{N}, \mathrm{ALG}}}{7}+\frac{40 \alpha_{\mathrm{P}, \mathrm{ALG}}}{31}$

$\mathrm{g} O / \mathrm{g} X \mathrm{ALG}$

$S_{\mathrm{CO} 2} \quad{ }^{-\alpha} \mathrm{C}, \mathrm{ALG}$

$\mathrm{g} C / \mathrm{g} X \mathrm{ALG}$

$S_{\mathrm{H}} \quad \frac{\alpha_{\mathrm{N}, \mathrm{ALG}}}{14}-\frac{2 \alpha_{\mathrm{P}, \mathrm{ALG}}}{31}$

molesH / g $X_{\mathrm{ALG}}$

$S_{\mathrm{H} 2 \mathrm{O}}-\frac{\alpha_{\mathrm{H}, \mathrm{ALG}}}{2}+\frac{3 \alpha_{\mathrm{N}, \mathrm{ALG}}}{28}+\frac{3 \alpha}{\mathrm{P}, \mathrm{ALG}}$

molesH $_{2} \mathrm{O} / \mathrm{g} X_{\mathrm{ALG}}$

$X_{\mathrm{ALG}}{ }^{1}$

$\mathrm{g} X_{\mathrm{ALG}} / \mathrm{g} X_{\mathrm{ALG}}$

(9b) Growth of algae with $\mathrm{NO}_{3}$ :
$s_{\mathrm{NO} 3}-\alpha_{\mathrm{N}, \mathrm{ALG}}$
$\mathrm{g} N / \mathrm{g} X \mathrm{ALG}$
$s_{\mathrm{HPO} 4}{ }^{-\alpha} \mathrm{P}, \mathrm{ALG}$
$\mathrm{g} P / \mathrm{g} X \mathrm{ALG}$ 


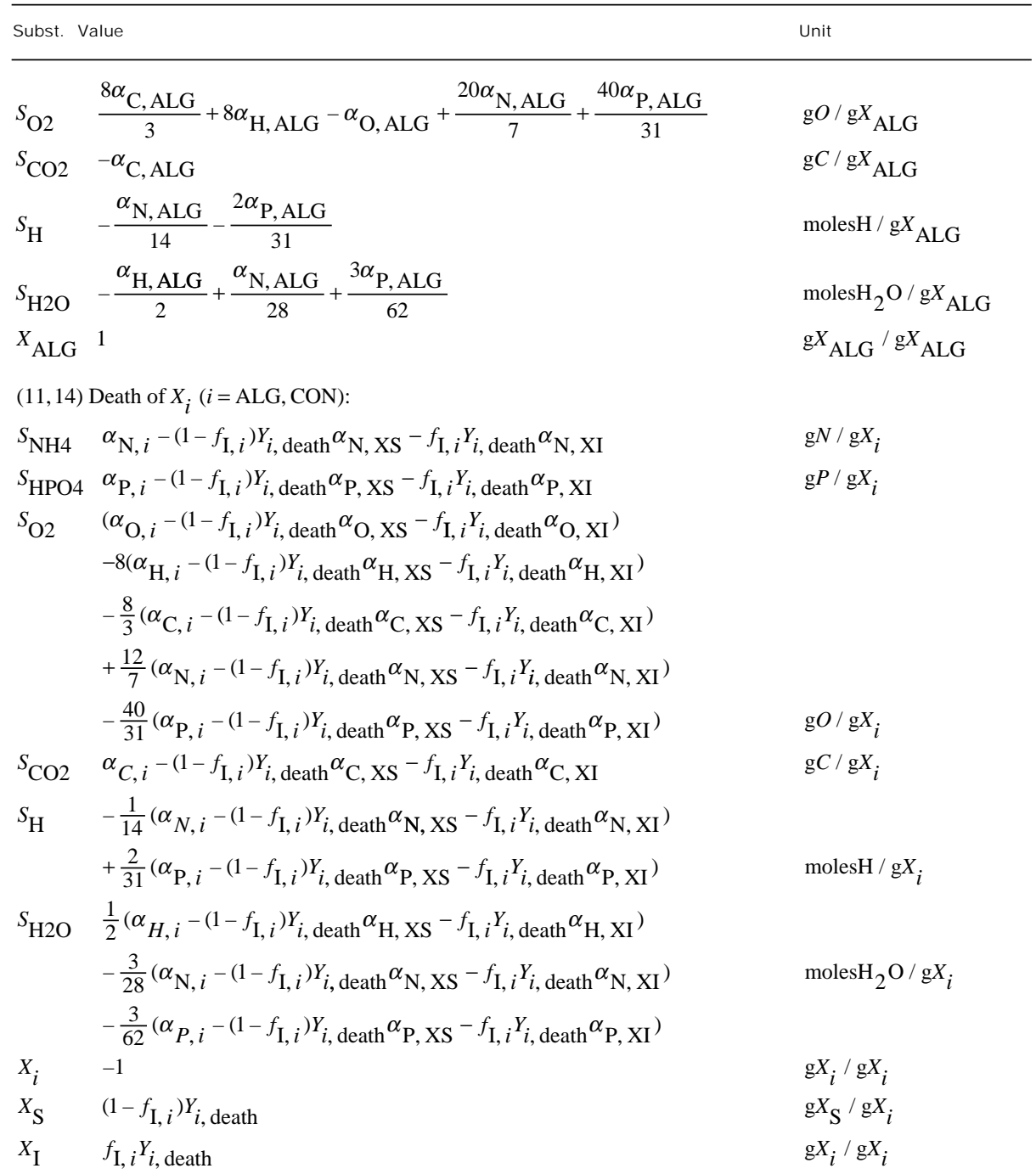

(12) Growth of consumers on $X_{i}(i=\mathrm{ALG}, \mathrm{S}, \mathrm{H}, \mathrm{N} 1, \mathrm{~N} 2)$ :

$\begin{array}{lll}S_{\mathrm{NH} 4} & \frac{\alpha_{\mathrm{N}, i}}{Y_{\mathrm{CON}}}-\frac{f_{e} \alpha_{\mathrm{N}, i}}{Y_{\mathrm{CON}}}-\alpha_{\mathrm{N}, \mathrm{CON}} & \mathrm{g} N / \mathrm{g} X_{\mathrm{CON}} \\ S_{\mathrm{HPO} 4} & \frac{\alpha_{\mathrm{P}, i}}{Y_{\mathrm{CON}}}-\frac{f_{e} \alpha_{\mathrm{P}, i}}{Y_{\mathrm{CON}}}-\alpha \mathrm{P}, \mathrm{CON} & \mathrm{g} P / \mathrm{g} X_{\mathrm{CON}} \\ S_{\mathrm{O} 2} & \left(\frac{\alpha_{\mathrm{O}, i}}{Y_{\mathrm{CON}}}-\frac{f_{e} \alpha_{\mathrm{O}, \mathrm{XS}}}{Y_{\mathrm{CON}}}-\alpha \mathrm{O}, \mathrm{CON}\right)-8\left(\frac{\alpha_{\mathrm{H}, i}}{Y_{\mathrm{CON}}}-\frac{f_{e} \alpha_{\mathrm{H}, \mathrm{XS}}}{Y_{\mathrm{CON}}}-\alpha_{\mathrm{H}, \mathrm{CON}}\right) & \\ & -\frac{8}{3}\left(\frac{\alpha_{\mathrm{C}, i}}{Y_{\mathrm{CON}}}-\frac{f_{e} \alpha_{\mathrm{C}, i}}{Y_{\mathrm{CON}}}-\alpha \mathrm{C}, \mathrm{CON}\right)+\frac{12}{7}\left(\frac{\alpha_{\mathrm{N}, i}}{Y_{\mathrm{CON}}}-\frac{f_{e} \alpha_{\mathrm{N}, \mathrm{XS}}}{Y_{\mathrm{CON}}}-\alpha_{\mathrm{N}, \mathrm{CON}}\right) \\ & -\frac{40}{31}\left(\frac{\alpha}{Y_{\mathrm{P}, i}}-\frac{f_{e} \alpha \mathrm{P}, \mathrm{XS}}{Y_{\mathrm{CON}}}-\alpha \mathrm{P}, \mathrm{CON}\right) & \mathrm{g} O / \mathrm{g} X_{\mathrm{CON}} \\ S_{\mathrm{CO} 2} & \frac{\alpha_{\mathrm{C}, i}}{Y_{\mathrm{CON}}}-\frac{f_{e} \alpha_{\mathrm{C}, \mathrm{XS}}}{Y_{\mathrm{CON}}}-\alpha{ }_{\mathrm{C}, \mathrm{CON}} & \mathrm{g} C / \mathrm{g} X_{\mathrm{CON}}\end{array}$ 


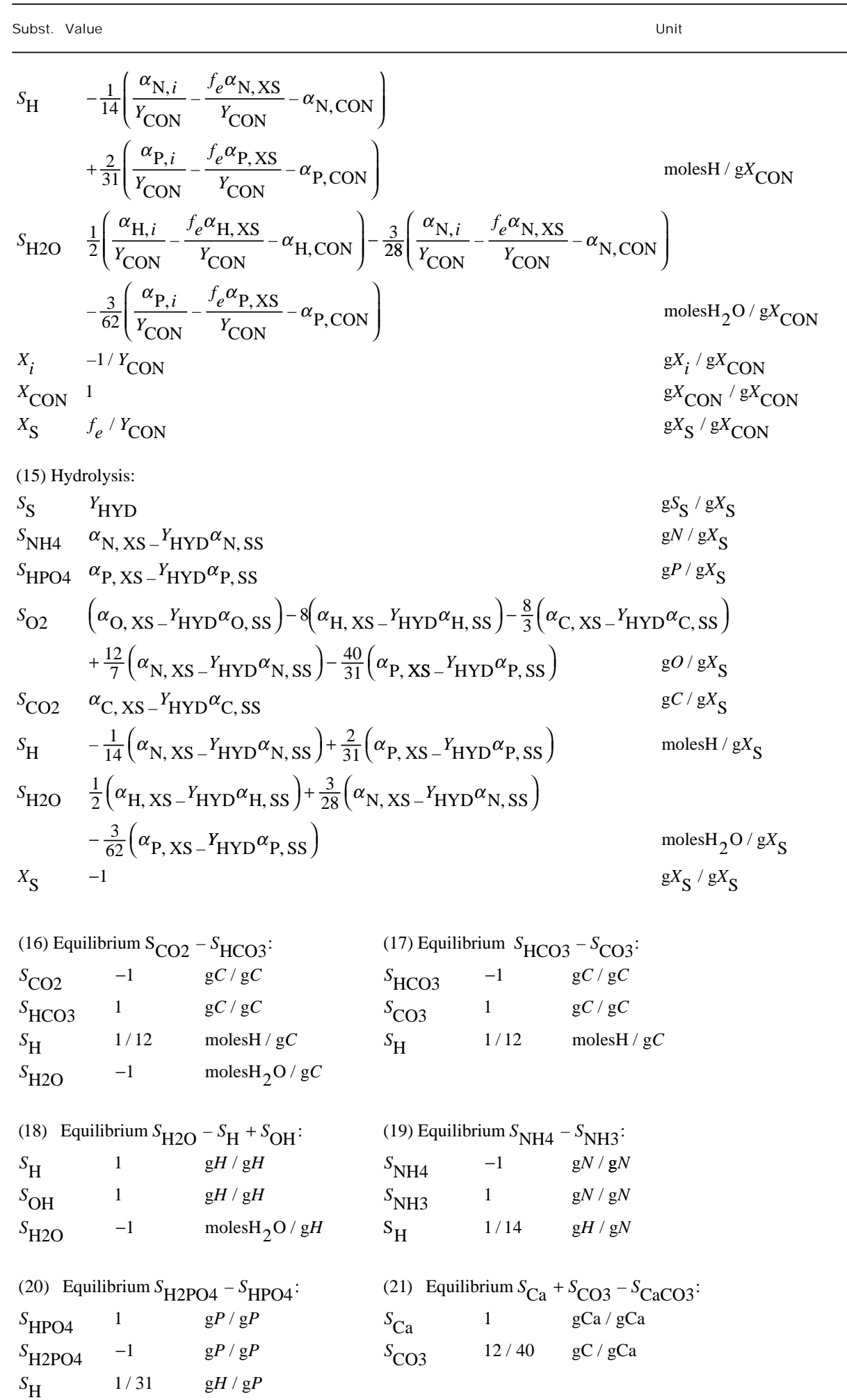




\section{Appendix 2: a numerical example}

The following tables give examples for numerical values of the stoichiometric parameters, the kinetic parameters and for the resulting stoichiometric coefficients. The numerical values given in these tables are not part of the river water quality model no. 1. Reasonable values were estimated based on literature on the composition of organic material, on the activated sludge models, on existing river water quality models, on the case studies following this paper, and on the experience of the authors.

Table 5 Mass fractions of elements on organic compounds

\begin{tabular}{lllllllllll}
\hline & $\mathbf{s}_{\mathrm{S}}$ & $\mathbf{s}_{1}$ & $\mathbf{x}_{\mathrm{H}}$ & $\mathbf{x}_{\mathrm{N} 1}$ & $\mathbf{x}_{\mathrm{N} 2}$ & $\mathbf{x}_{\mathrm{ALG}}$ & $\mathbf{x}_{\mathrm{CON}}$ & $\mathbf{x}_{\mathrm{S}}$ & $\mathbf{x}_{1}$ & Unit \\
\hline$\alpha_{\mathrm{C}}$ & 0.57 & 0.61 & 0.52 & 0.52 & 0.52 & 0.36 & 0.36 & 0.57 & 0.61 & $\mathrm{gC} / \mathrm{gOM}$ \\
$\alpha_{H}$ & 0.08 & 0.07 & 0.08 & 0.08 & 0.08 & 0.07 & 0.07 & 0.08 & 0.07 & $\mathrm{gH} / \mathrm{gOM}$ \\
$\alpha_{0}$ & 0.28 & 0.28 & 0.25 & 0.25 & 0.25 & 0.50 & 0.50 & 0.28 & 0.28 & $\mathrm{gO} / \mathrm{gOM}$ \\
$\alpha_{\mathrm{N}}$ & 0.06 & 0.03 & 0.12 & 0.12 & 0.12 & 0.06 & 0.06 & 0.06 & 0.03 & $\mathrm{gN} / \mathrm{gOM}$ \\
$\alpha_{\mathrm{P}}$ & 0.01 & 0.01 & 0.03 & 0.03 & 0.03 & 0.01 & 0.01 & 0.01 & 0.01 & $\mathrm{gP} / \mathrm{gOM}$ \\
\hline
\end{tabular}

Table 6 Stoichiometric parameters

\begin{tabular}{|c|c|c|c|c|c|c|c|c|}
\hline Symbol & Value & Unit & Symbol & Value & Unit & Symbol & Value & Unit \\
\hline$Y_{\mathrm{H}, \text { aer }}$ & 0.60 & $g X_{H} / g S_{S}$ & $Y_{\mathrm{N} 2}$ & 0.03 & $\mathrm{gX}_{\mathrm{N} 2} / \mathrm{gS}_{\mathrm{NO} 2^{-\mathrm{N}}}$ & $f_{I, C O N}$ & 0.20 & $g X_{I} / g\left(X_{S}+X_{l}\right)$ \\
\hline $\mathrm{Y}_{\mathrm{H}, \text { anox, NO3 }}$ & 0.50 & $g X_{H} / g S_{S}$ & $f_{I, A L G}$ & 0.20 & $g X_{1} / g\left(X_{S}+X_{1}\right)$ & $Y_{\text {CON, death }}$ & 0.62 & $g\left(X_{S}+X_{l}\right) / g X_{\text {CON }}$ \\
\hline $\mathrm{Y}_{\mathrm{H} \text {, anox,NO2 }}$ & 0.30 & $g X_{H} / g S_{S}$ & $Y_{A L G \text {, death }}$ & 0.62 & $g\left(X_{S}+X_{I}\right) / g X_{A L G}$ & $Y_{H Y D}$ & 1.00 & $g S_{S} / g X_{S}$ \\
\hline$Y_{N 1}$ & 0.13 & $g X_{N 1} / g S_{N H 4}-N$ & $f_{e}$ & 0.40 & $g X_{S} / g X_{\text {CON }}$ & & & \\
\hline
\end{tabular}

Table 7 C hemical equilibria (S tumm and Morgan, 1981; Sigg and Stumm, 1994; modified, T in ${ }^{\circ} \mathrm{C}$ )

\begin{tabular}{|c|c|c|c|c|c|}
\hline Symbol & Value & Unit & Symbol & Value & Unit \\
\hline $\mathrm{K}_{\mathrm{eq}, \mathrm{w}}$ & $10^{-4470.99 /(273.15+T)+12.0875-0.01706(273.15+T)}$ & $\mathrm{gH}^{2} / \mathrm{m}^{6}$ & $\mathrm{~K}_{\mathrm{eq}, \mathrm{N}}$ & $10^{2.891-2727 /(273.15+\mathrm{T})}$ & $\mathrm{gH} / \mathrm{m}^{3}$ \\
\hline $\mathrm{K}_{\mathrm{eq}, 1}$ & $10^{17.843-3404.71 /(273.15+\mathrm{T})-0.032786(273.15+\mathrm{T})}$ & $\mathrm{gH} / \mathrm{m}^{3}$ & $K_{e q, P}$ & $10^{-3.46-219.4 /(273.15+T)}$ & $\mathrm{gH} / \mathrm{m}^{3}$ \\
\hline $\mathrm{K}_{\mathrm{eq}, 2}$ & $10^{9.494-2902.39 /(273.15+\mathrm{T})-0.02379(273.15+\mathrm{T})}$ & $\mathrm{gH} / \mathrm{m}^{3}$ & $\mathrm{~K}_{\mathrm{eq}, \mathrm{s} 0}$ & $12.40 .10^{19.87-3059 /(273.15+\mathrm{T})-0.04035(273.15+\mathrm{T})}$ & $\mathrm{gC}$ agC $/ \mathrm{m}^{6}$ \\
\hline
\end{tabular}

Table 8 Kinetic parameters ( $T_{0}$ is equal to $20^{\circ} \mathrm{C}$ )

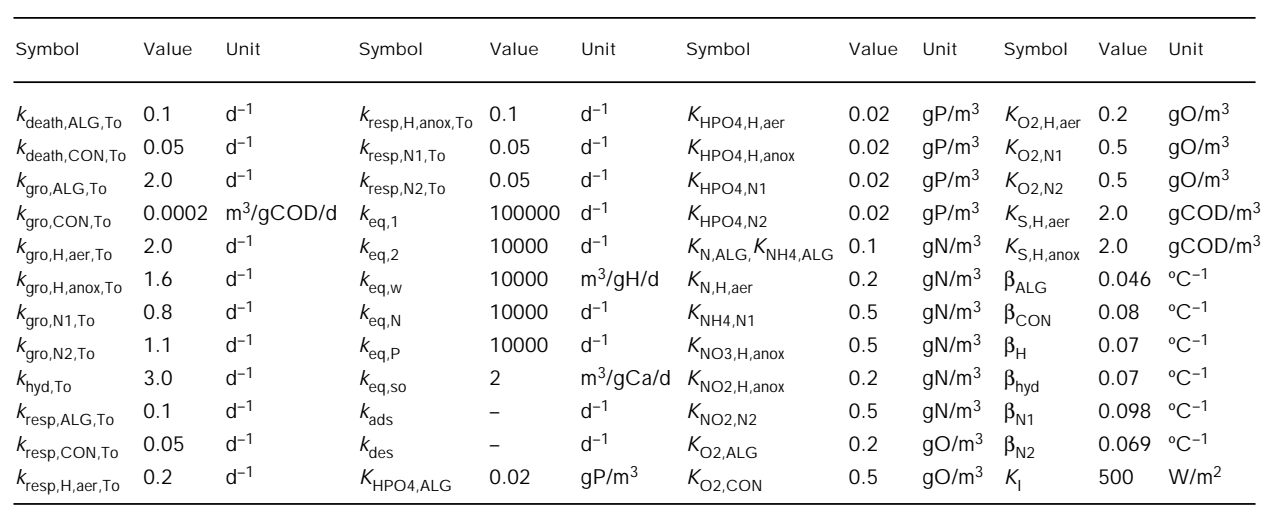


Table 9 Stoichiometric coefficients based on the parameters given in Tables 5 and 6 .

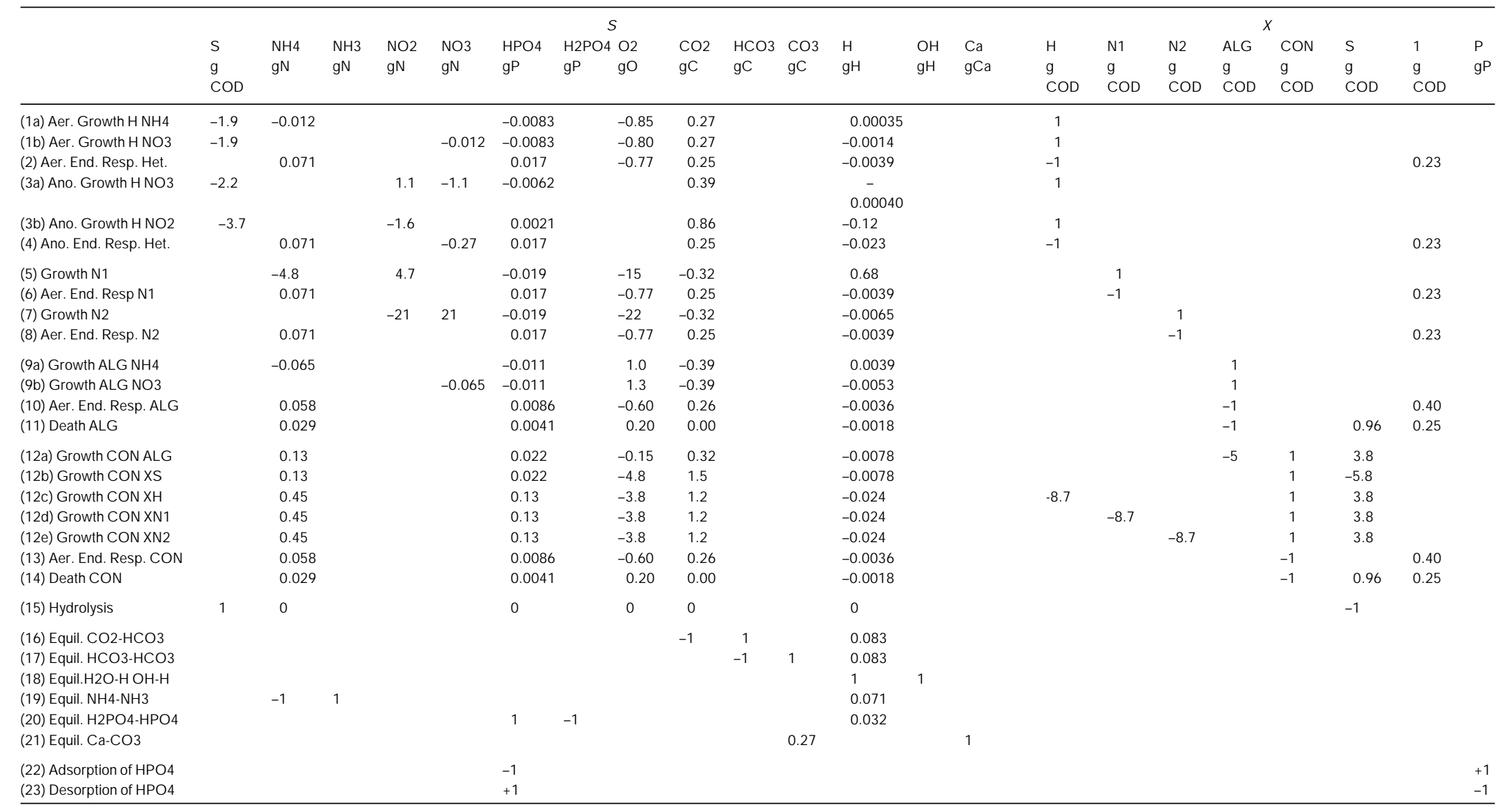




\section{References}

Borchardt, D. and Reichert, P. (2001). River Water Quality Model No. 1 (RWQM1): Case study I. Compartmentalisation approach applied to oxygen balances in the river Lahn (Germany). Wat. Sci. Tech., 43(5) 41-49 (this issue).

Brown, L.C. and Barnwell, T.O. (1987). The Enhanced Stream Water Quality Models QUAL2E and QUAL2E-UNCAS: Documentation and User Manual. Report EPA/600/3-87/007, U.S. EPA, Athens, GA, USA.

Elser, J.J., Chrzanowski, T.H., Sterner, R.W., Schampel, J.H. and Foster, D.K. (1995). Elemental ratios and the uptake and release of nutrients by phytoplankton and bacteria in three lakes of the Canadian shield. Microbial Ecology, 29, 145-162.

Elser, J.J. and Urabe, J. (1999). The stoichiometry of consumer-driven nutrient recycling: Theory, observations, and consequences. Ecology, 80(3), 735-751.

Fagerbakke, K.M., Heldal, M. and Norland, S. (1996). Content of carbon, nitrogen, oxygen, sulfur and phosphorus in native aquatic and cultured bacteria. Aquatic Microbial Ecology, 10, 15-27.

Henze, M., Gujer, W., Takashi, M. and van Loosdrecht, M. (2000). Activated Sludge Models ASM1, ASM2, ASM2D and ASM3. Scientific and Technical Report No. 9, IWA Publishing, London.

Lesouef, A., Payraudeau, M., Rogalla, F. and Kleiber, B. (1992). Optimizing nitrogen removal reactor configurations by on-site calibration of the IAWPRC activated sludge model. Wat. Sci. Tech., 25(6), 105-123.

Norland, S., Fagerbakke, K.M. and Heldal, M. (1995). Light element analysis of individual bacteria using X-ray microanalysis. Applied Environmental Microbiology, 61, 1357-1362.

Nowak, O., Franz, A., Svardal, K., Muller, V. and Kuhn, V. (1999). Parameter estimation for activated sludge models with the help of mass balance. Wat. Sci. Tech., 39(4), 113-120.

Rauch, W., Henze, M., Koncsos, L., Reichert, P., Shanahan, P., Somlyódy, L. and Vanrolleghem, P. (1998). River Water Quality Modelling: I. State of the Art. Wat. Sci. Tech., 38(11), 237-244.

Reichert, P. (2001). River Water Quality Model No. 1 (RWQM1): Case study II. Oxygen and nitrogen conversion processes in the River Glatt (Switzerland). Wat. Sci. Tech., 43(5) 1-9 (this issue).

Rheinheimer, G., Hegemmann, W., Raff, J. and Sekoulov, I. (1988). Stickstoffkreislauf im Wasser, Oldenbourg, München.

Shanahan, P., Henze, M., Koncsos, L., Rauch, W., Reichert, P., Somlódy, L. and Vanrolleghem, P. (1998). River Water Quality Modelling: II. Problems of the Art. Wat. Sci. Tech., 38(11), 245-252.

Shanahan, P., Borchardt, D., Henze, M., Rauch, W., Reichert, P., Somlyódy, L. and Vanrolleghem, P. (2001). River Water Quality Model No. 1 (RWQM1): I. Modelling approach. Wat. Sci. Tech., 43(5) 1-9 (this issue).

Sigg, L. and Stumm, W. (1994). Aquatische Chemie, vdf/Teubner, Zürich/Stuttgart.

Somlyódy, L., Henze, M., Koncsos, L., Rauch, W., Reichert, P., Shanahan, P. and Vanrolleghem, P. (1998). River Water Quality Modelling: III. Future of the Art. Wat. Sci. Tech., 38(11), 253-260.

Streeter, W.H. and Phelps, E.B. (1925), A study of the pollution and natural purification of the Ohio River, Public Health Bull. 146, U.S. Public Health Service, Washington D.C.

Stumm, W. and Morgan, J.J. (1981), Aquatic Chemistry, Wiley, New York.

Vanrolleghem, P., Borchardt, D., Henze, M., Rauch, W., Reichert, P., Shanahan, P. and Somlyódy, L. (2001). River Water Quality Model No. 1 (RWQM1): III. Biochemical submodel Selection. Wat. Sci. Tech., 43(5) 31-40 (this issue).

Vanrolleghem, P.A., Spanjers, H., Petersen, B., Ginestet, P. and Takacs, I. (1999). Estimating (combinations of) Activated Sludge Model No.1 parameters and components by respirometry. Wat. Sci. Tech., 39(1), 195-214. 